\title{
The Law of Descent of the Mind: Law, History, and Civilization in Antebellum Literary Addresses
}

\author{
Daniel M. Filler \\ Drexel University - Thomas R. Kline School of Law, daniel.m.filler@drexel.edu \\ Alfred L. Brophy \\ University of Alabama - School of Law, abrophy@law.ua.edu
}

Follow this and additional works at: https://scholarship.law.ua.edu/fac_working_papers

\section{Recommended Citation}

Daniel M. Filler \& Alfred L. Brophy, The Law of Descent of the Mind: Law, History, and Civilization in Antebellum Literary Addresses, (2005).

Available at: https://scholarship.law.ua.edu/fac_working_papers/24

This Working Paper is brought to you for free and open access by the Faculty Scholarship at Alabama Law Scholarly Commons. It has been accepted for inclusion in Working Papers by an authorized administrator of Alabama Law Scholarly Commons. 


\title{
THE UNIVERSITY OF ALABAMA SCHOOL OF LAW
}

\author{
"The Law of Descent of the Mind": \\ Law, History, and Civilization in \\ Antebellum Literary Addresses
}

Alfred L. Brophy

This paper can be downloaded without charge from the Social Science Research Network Electronic Paper Collection: http://ssrn.com/abstract=777724 


\title{
"The Law of Descent of the Mind": \\ Law, History, and Civilization \\ in Antebellum Literary Addresses
}

\author{
Alfred L. Brophy ${ }^{1}$
}

Abstract

In the antebellum era, literary addresses were a common and popular form of public expression. Legal historians have profitably mined fourth of July orations and addresses in Congress for insight into the intellectual worlds of the antebellum era. Yet, they have made virtually no use of the literary address, which are aimed at a different and more elite audiences. This essay employs a close analysis of nearly forty addresses given at the University of Alabama from 1832 through 1860 to gauge the changes in thought in the antebellum South on political theory and jurisprudence. It uses the addresses to create a picture of the world view of the judges.

The addresses, moreover, illustrate the changes from Enlightenment ideas of moral and technological progress to a static, proslavery vision of the late antebellum period. They allow us to assess the orators' intellect, interests, and knowledge, and belief systems. The addresses illustrate a wide-ranging respect for ideas, including the abolition of capital punishment, the scholar's search for truth against the tide of public opinion, republicanism, democracy, and radicalism in American politics, and the importance of slavery to Southern culture. A final section turns to judicial opinions in Alabama to make a preliminary sketch of the ways that some of the ideas expressed in the addresses correlate with the moral philosophical views of judges.

The addresses, thus, emerge as important windows into antebellum Southern thought and as vehicles for mapping in detail the intellectual world of moral and political philosophy inhabited by southerners, particularly judges and legislators in the years leading into Civil War. Finally, the essay begins to sketch key pieces of jurisprudence (such as considerations of utility, the importance of history and culture, and morality), as it provides a model of how to mine the hundreds of addresses delivered to other literary societies, north and south, in the years before Civil War for insights into legal thought.

\footnotetext{
1 Professor of Law, The University of Alabama.

I would like to thank Mary Sarah Bilder, Mark E. Brandon, David Durham, Daniel M. Filler, Daniel Hulsebosch, William S. Brewbaker, Gregory M. Dorr, Guy Hubbs, Lawrence F. Kohl, Arthur G. LeFrancois, Paul Pruitt, Jessica Lacher-Feldman, Merrily Harris, and the staff of the William Hoole Special Collections Library at the University of Alabama, as well as two terrific research assistants, Rebecca Schwartz and Clayton Taylor, whose work on an earlier project benefitted this one as well.
} 
In the years before Civil War, colleges throughout the country gathered their students and faculties together to listen to orations sponsored by literary societies. ${ }^{2}$ The students heard wideranging orations. Speakers often emphasized the importance of learning and sought to justify the place of the University in American life. They emphasized moral and technological progress and the contributions of learning to that process. They also frequently linked that learning to issues in moral philosophy and law. At the University of Alabama, students gathered at the end of the academic year in the University's Rotunda, unfurled their Literary Society's banner, and listened for hours. ${ }^{3}$ The addresses taught the special place of educational institutions and the educated in Alabama society.

This essay surveys the ideas in the nearly forty orations given at the University of Alabama in the antebellum period. It suggests some of the ways that orations represented the values of the University and the larger Alabama intellectual community and the changes in those values in the years leading into the Civil War. This essay is designed to accomplish several goals. First, to recover the richness of the antebellum University of Alabama literary addresses. Second, to mine those addresses for some evidence of the changing nature of thought at the University and to link those changes to Alabama culture more generally. Third, and most speculatively, to link the ideas in those addresses to Alabama legal thought. That is, this paper is part of an on-going recovery of the long-forgotten connections between moral philosophy and legal thought in the antebellum south. For we are only now beginning to glimpse the diversity of antebellum intellectual life and its connections to legal thought. ${ }^{4}$

\footnotetext{
2 See, e.g., Kenneth Sacks, Understanding Emerson: "The American Scholar" and His Struggle for SElf-Reliance _ (2003) (discussing antebellum literary society orations); Clark Sutherland Nort hup, a Bibliography of the Phi Beta Kappa Society (1928) (listing all known nineteenth-century Phi Beta Kappa orations and poems); Marta Wagner, The American Scholar in the Early National Period : the Changing Context of College Education, 1782-1837 (Ph.D. dissertation, Yale University, 1983). Robert AbZug, Passionate Liberator: Theodore Dwight Weld and the Dilemma of Reform __ (1980) (discussing radical abolitionists' literary addresses).

3 John G. Barr, Contributions of Science to the Uses of Man. Anniversary Oration of Boykin Burwell 35 (Tuscaloosa, Observer Office, 1857) (describing scene of oration, including presence of women and alumni in the audience). See also Adelbert Edward Bradley, An Historical Analysis of the Speech Activities of the Literary Societies at the University of Alabama from 1831 to 1912 (M.A. thesis, University of Alabama, 1951).

4 See, e.g., Charles Barzun, Common Sense and Legal Science, 90 VA. L. Rev. 1051 (2004); Alfred L. Brophy, Reason and Sentiment: The Moral Worlds and Modes of Reasoning of Antebellum Jurists, 79 B.U. L. REV. 1131 (1999) (discussing the moral philosophy of antebellum jurists and using moral philosophy texts to explore it); Alfred L Brophy, The Rule of Law in Antebellum College Literary Addresses: The Case of William Greene, 26 CuMB. L. REV. 231-85 (2001) (exploring William Greene's 1850 address at Brown University, which supported the Fugitive Slave Act of 1850 ); Reuel Schiller, Conflicting Obligations; Slave Law and the Late Antebellum North Carolina Supreme Court, 78 VA. L. REv. 1207 (1992). We have some very rich explorations of antebellum legal thought. See, e.g., Michael O’Brien, A Character of Hugh Legaré (1983); G. Edward White, The Marshall Court and Cultural Change, $1815-1835$ (1988); Stephen Siegel, The Marshall Court and Republicanism, 67 Tex. L. Rev. 903 (1989); Susanna L. Blumenthal, Law and the Creative Mind, 74 Chi.- Kent L. Rev. 151 (1998). Other scholarship connects legal thought to antebellum romanticism or the search for reason. See, e.g., Anne C. Dailey, Holmes and the Romantic Mind, 48 Duke L.J. 429 (1998); John H. Langbein, Chancellor Kent and the History of Legal Literature, 93 Colum. L. REv. 547 (1993). Some look to legal education for evidence of the nature of
} 


\section{The Intellectual and the Orator A. Functions of Oratory}

There is a growing appreciation of the connections between public addresses and intellectual thought. We have studies of public addresses in the early national period, particularly in New England. ${ }^{5}$ Those studies, such as Robert D. Brown's Knowledge is Power, Sandra Gustafson's Eloquence is Power, and Christopher Grasso's A Speaking Aristocracy, point to the ways that public addresses reflect attitudes and the political structure, what is now commonly known as "authority." They also suggest ways that the addresses affirm and even in some cases create that authority.

It may be trite to observe that much of the political and social debate took place through public addresses. Historians frequently center their analysis around public addresses, such as the Webster-Hayne debate over the tariff in $1832,{ }^{6}$ the addresses around the Compromise of $1850,{ }^{7}$ and Georgia's debate over secession in late $1860,{ }^{8}$ to take only three examples. Speech was the form of much debate; analysis of contents of speeches tell us much about the beliefs and aspirations of the speakers and their audience. The speeches also tell us much about how politicians mobilized support for their positions, how they drew upon common cultural images and themes to garner support.

Many orations served stabilizing purposes and helped auditors to construct meanings in their world. In charges to grand juries, judges frequently used their authority to influence the public mind. Grand jury charges, which gained their greatest popularity during the age of Federalism, permitted judges to alert juries to issues of public concern. Many Fourth of July

antebellum legal thought. See, e.g., Andrew M. Siegel, "To Learn and Make Respectable Hereafter": The Litchfield Law School in Cultural Context, 73 N.Y.U.L. REV. 1978, 2003 (1998); Norman W. Spaulding, The Myth of Civil Republicanism: Interrogating the Ideology of Antebellum Legal Ethics, 71 FordHAM L. REV. 1397 (2003); Lawrence Jenab \& M.H. Hoeflich, Forensic Oratory in Antebellum America, 51 U. KAN. L. ReV. 449 (2003).

5 See, e.g., Sandra Gustafson, Eloquence is Power: Oratory \& Performance in Early America (2000); Christopher Grasso, A Speaking Aristocracy: Transforming Public Discourse in Eighteenth-Century CONNECTICUT 144-89 (1999) (discussing public dispute over governance of Yale College); RoBERT S. BROWN, KNOWLedge is Power (1985).

6 One might also think of Daniel Webster's addresses more generally. See, e.g., Robert A. FerGuson, LAw AND Letters in American Culture. (1984) (discussing Webster). One of the great needs for antebellum history is a southern counterpart to Law and Letters in American Culture. Such a study would include literary addresses, the Southern Quarterly Review, Southern Literary Messenger, Southern Review, fiction authors such as Nathan Beverly Tucker, John Pendelton Kennedy, Caroline Hentz, William Gilmore Simms, as well as the extraordinary output of judicial opinions and legal treatises, such as T.R.R. Cobb's Law of Slavery, Sawyer's Southern Institutes, and nonlawyer Thomas Roderick Dew's A Digest of the Laws, Customs, and Manners of Ancient and Modern Nations (1853).

7 Merrill Peterson, The Great Triumvirate: Webster, Clay, and Calhoun (1986).

8 See Secession Debated: Georgia’s Showdown in 1860 (William W. Freehling \& Craig M. Simpson eds. 1992); Michael P. Johnson, Tow ard a Patriarchal Republic: The Secession of Georgia (1977). 
orations were the basis for celebrating past achievements. ${ }^{9}$ Those orations, which historians have mined for substantial insight into American culture, are well-suited to tell us about aspirations. How do we celebrate our history, what is the meaning of the struggle for freedom? What is its future? Particularly in the years leading into Civil War, Fourth of July speeches were used to assure that the Union still had value. University of Alabama Professor Frederick A. P. Barnard (and later president of Columbia University) delivered a pro-Union oration in $1851 .{ }^{10}$

Sometimes the orations criticized the ways that the current generation had failed to fulfill their mission. One long-neglected example of that criticism is George Bancroft's attack on Whiggery, which he delivered in western Massachusetts on July 4, $1837 .{ }^{11}$ At other times, a Fourth of July speech might be quite destabilizing. Frederick Douglass asked in an address at Rochester, "What have I . . to do with your independence?"12 Douglass' question pointed out a central question for Americans in the years heading into Civil War.

Many have written about the subversive aspects of speech, about the ways that speech can challenge authority. In the antebellum period in particular, public speeches were frequently occasions for presenting radical interpretations. During New York's anti-rent movement from the late 1830s through the Civil War, speeches were commonly occasions for advocating altering rules that permitted redistribution of property. ${ }^{13}$ Speeches, particularly one by Daniel Barnard to the Yale Phi Beta Kappa Society, were also used to oppose the "fanaticism" of the anti-renters. ${ }^{14}$

9 See, e.g., Andrew Burstein, America's Jubilee: How in 1826 a Generation Remembered Fifty Years of INDEPENDENCE 228-54 (2001).

10 Frederick A P Barnard, No Just Cause For a dissolution of the Union in ANy thing Which has hitherto

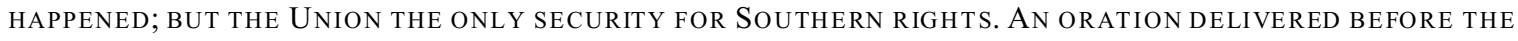
Citizens of Tuscaloosa, Ala., July 4th, 1851 (Tuscaloosa, Printed by J.W. \& J.F. Warren, Observer Office 1851).

11 George Bancroft, An Oration Delivered Before the Democracy of Springfield . . July 4,1836 (Springfield, George and Charles Merriam 1836).

12 What to the Slave is the Fourth of July?, in The OXFord Frederick Douglass Reader 108, 115 (William L. Andrews ed., 1996).

13 See, e.g., Charles McCurdy, The Anti-Rent Era in New York Law And Politics, 1839-1865 (2002).

14 See Daniel Barnard, Man and the State: Social and Political: An Address Delivered Before the Connecticut Alpha of Phi Beta Kappa at Yale College (B.L. Hamlen, New Haven 1846). One might make much of Barnard's multiple addresses, to construct a portrait of his political ideology, which emphasized property and stability. See Daniel D Barnard, An Address Delivered Before the Philoclean and Peithesopian Societies of Rutgers College: At the Request of the Philoclean Society, July 18, 1837, on the day Preceding the annual commencement (Albany, Hoffman \& White, 1837); Daniel D. Barnard, An Address Delivered at Amherst, Before the Literary Societies of Amherst College, August 27, 1839 (Albany, Hoffman \& White, 1839) (asking for broader diffusion of knowledge and warning about tendencies in the popular mind to be led astray). Daniel Barnard, The Social System. An Address pronounced before the House of Convocation, of Trinity College, Hartford, August 2, 1848 (Hartford, Samuel Hanmer, Jr. 1848 ); Daniel D. Barnard, a Discourse Pronounced at Burlington Before the Literary Societies of the University of Vermont, ... 1838 (Albany, N.Y., Hoffman \& White, 1838); Daniel D. BARnARd, A Discourse Pronounced AT Schenectady, before the New-York Alpha, of the Society of Phi Beta Kappa, July 25th, 1837 (Albany, 
Public addresses were a popular vehicle for disseminating reform ideas. Meetings of temperance and bible societies, colonization and abolition societies, often used public addresses. Frequently they published those addresses, so that they might reach a wider audience. One may measure the popularity of published addresses as a vehicle of communication by looking at the number of addresses discussed in literary magazines, such as the North American Review, ${ }^{15}$ the United States Magazine and Democratic Review, ${ }^{16}$ and the Southern Literary Messenger. ${ }^{17}$

\section{B. Oratory as Evidence}

While the best-known literary address, Ralph Waldo Emerson's "American Scholar," presented a destabilizing vision, Emerson was in the minority in the antebellum era. Those looking for subversion through speech are unlikely to find it at southern literary societies. For antebellum literary societies were places for celebration of hierarchy. At Northern and Southern colleges, addresses commonly celebrated order and moderate progress. Colleges were places where students were disciplined to follow and accept such traditional values as obedience to established thought, patience, and hierarchy, as well as universal values like hard work and patriotism.

Historians have made effective use of Northern orations in particular in reconstructing the

Hoffman \& White, 1837).

15 See, e.g., Learned Societies, 8 N. Am. REv. 157 (1818) (discussing addresses by De Witt Clinton and Timothy Ford); Everett's Speeches, 44 N. Am. Rev. 588 (1837); Phi Beta Kappa Orations, 24 N. Am. ReV. 129 (1827); Bushnell's Phi Beta Kappa Oration, 46 N. Am. Rev. 301 (1838); Goddard's Address, 44 N. Am. Rev. 551 (1837); Ware's Vision of Liberty, 19 N. Am. Rev. 468 (1824). See also An Address Delivered Before the Union Literary Society of Miami University. By Timothy Walker, 3 New-England Mag. 513 (1832).

16 See, e.g., The Law of the Progress of the Race, 15 U.S. Demo. Rev. 195 (1844) (discussing MARK HopkIns, AN Address Before the Society of Alumni of Williams College (1843)); Unitarian Portraits, 15 U.S. Dem. Rev. 389, 396 (1844) ("The literary address, in the hands of Everett, has become a classic form of writing: a species of oratory the growth of the present centrury. Differing from the lecture, in being less strictly didactic, it is the elaborate eloquence of the fine scholar. The occasions of its display are generally either the celebration of a literary festival, or an epoch of a political history; or eulogies of the sorts so common with the French wits. Of these three classes, are the admirable orations before the Phi Beta Kappa Society, the orations at Plymouth, Concord, Worcester, Cambridge, Charlestown, and Lowell, and the masterpiece of Lafayette."). See also Nationality in Literature, 20 U.S. Dem. Rev. 262, 271 (1847); An Address, Pronounced Before the Phi Beta Kappa Society of Union College . . . 9 U.S. DEM. REV. 630 (1841)

17 See, e.g, James A. Hillhouse, 7 S. Lit. Messenger 329, 333 (1841); Literary Societies, 1 Southern Liter ARy Gazette 58-61 (1828). Address Delivered Before the Philodemic Society of Georgetown, D. C., 6 Southern Lit. Messenger 232 (1840); [William Gilmore Simms,] Popular Discourses and Orations, 4 S. Q. ReV. $317-351$ (1851); James Mercer Garnett, Address on Literary Associations to Promote Education, 1 S. LIT. MESSENGER $282-$ 290 (1835); Lucian Minor, An Address on Education, 2 S. Lit. Messenger 17-24 (1835); Address, by Henry St. George Tucker, 2 S. Lit. Messenger 258-259 (1836); Thomas Roderick Dew, An Address on the Influence of the Federative Republican System of Government Upon Literature and the Development of Character, 2 S. LIT. messenger 261-282 (1836); Hon. John Tyler, An Address Delivered Before the Two Literary Societies of Randolph Macon College, Virginia, 5 Southern Lit. Messenger 20-25 (1839); Benjamin Johnson Barbour, Address: Delivered before the Literary Societies of the Virginia Military Institute, July 4th, 1854, 20 S. LIT. MESSENGER 513528 (1854); St. George Tucker, A Poetical Address, S. Lit. Messenger 113-121(1857). 
nature of thought. Perry Miller's Life of the Mind, to take one prominent example, relied in important ways on public statements, including addresses, to gauge the nature of legal thought. ${ }^{18}$ There are remarkable gaps in Miller's volume, however. There is great reliance on a few Whig thinkers: Daniel Webster, Joseph Story, and James Kent. That leads to a bias in favor of Whig thought at the expense of Democratic thought, which appears in the volume mostly through unrepresentative radicals like William Sampson. ${ }^{19}$ The literary addresses offer some promise of peering inside the mind of the orator. There are several questions they may help us answer-about the nature of the mind of the old south and the place of the University in it.

\section{University of Alabama Oratory in Particular}

The addresses at Alabama have three key virtues for us. First, they illustrate the vibrant ideas in circulation in antebellum Tuscaloosa. Michael O'Brien recently observed that there were significant thinkers in the Old South associated with Georgia, Alabama, Maryland, Mississippi, and Louisiana. Those thinkers were "usually associated with urban centers like Savannah, Tuscaloosa, Baltimore, Natchez, and New Orleans." 20 It is significant for Tuscaloosa that it receives a place of such prominence in O'Brien's catalog of urban centers that fostered intellectuals. That is a recognition of its importance as a center of education and politics. For Tuscaloosa was a place where newspaper editors, college professors and other teachers, such as novelist Caroline Hentz, ${ }^{21}$ judges, planters, members of the state house and senate, and businessmen met, along with frequent visitors ranging from James Birney to William Gilmore Simms. ${ }^{22}$ It had a lyceum, as well as the University and numerous churches.

18 See Perry Miller, The life of the Mind in America: From Revolution Through Civil War (1966).

19 Miller 1963 edited volume, The Legal Mind in America, provides excerpts from many of his most important sources. It presents some of the radical responses, such as William Sampson and Robert Rantoul's Oration at Scituate.

201 Michael O’Brien, Conjectures of Order: Intellectual Life and the American South, 1800-1860 15 (2004).

21 Caroline Lee Hentz, Human and divine philosophy: a poem, written for the Erosophic Society of the University of Alabama ... And recited by A.W. Richardson, December 12th, 1843 (Tuscaloosa, Journal and Flag Office, 1844). Richardson was on the faculty and served as librarian. See also Caroline Lee HentZ, An AdDress: Written by ReQuest, for the La Fayet te society of La Grange College... (Florence, Ala., The Florence Gazette office, 1842).

22 See, e.g., Philip Beidler, First Books: The Printed Word and Cultural Formation in Early Alabama (1999). Johanna Shields, A Sadder Simon Suggs: Freedom and Slavery in the Humor of Jackson Hooper, J. S. Hist. 641 (1990). There is much to deal with in the recovery of the intellectual world of antebellum Tuscaloosa, including the lyceum, the Female Seminary, the state legislature, the Supreme Court, and the University. See, e.g., Alva Woods, Introductory Address Delivered Before the Lyceum of Tuscaloosa, Alabama, June 11, 1831, in Alva Woods, Literary and Theological Addresses by Alva Woods, D.D. at 37, 57 (Providence, 1868) (“Are you a true American patriot? It is only by enlightening the people that you can hope that our liberties will be preserved, and that our republic will not, like the republics which have gone before us, fall a prey to anarchy and despotism.").

There has already been some very thoughtful work on intellectual life in antebellum Tuscaloosa,. See Beidler, supra; John W. Quist, Restless Visionaries: The Social Roots of Antebellum Reform in Alabama 
The University of Alabama addresses also illustrate the role of education. That is, they are part of the recovery of the thoughtful world of antebellum universities. Public addresses illustrate the ideas in circulation and contributed to building an identity for the University. They help to place students' understanding and courses into context. Edward Bullock's conclusion of his oration illustrates those goals. He sought to "hold up to admiration the peculiar civilization of the South" and, he seemed pleased to say, the University of Alabama was the ideal place to support that peculiar civilization. For, he asked, where would have been a better place to defend Southern institutions "than before this assembly of her patriot scholars?"23

Finally, they illustrate--and one suspects helped create-the minds of the Old South. The output of the Erosophic and Philomathic Societies, the alumni addresses, and other addresses at Alabama testify to a well-developed culture, which has been not yet been fully studied.

The process of describing Tuscaloosa's intellectual world is not completed. In fact, very

and Michigan (1998); A. James Fuller, Chaplain to the Confederacy: Basil Manly and Baptist Life in the Old South 142-45 (2000); Elizabeth Fox-Genovese, Within the Plantation Household: Black and White Women of the Old South 7-9 (1989) (discussing Sarah Gayle's visits to Tuscaloosa). James Sellers' comprehensive History of the University of Alabama (1953) has not received the attention that his detailed, thorough scholarship deserves. It may be due in part to its appearance in the form of a University history, which many readers may have mistaken for hagiography. It may, similarly, be due to his companion volume, Slavery in Alabama (1950), which, despite its deep research has fallen into disfavor recently because of certain statements that might strike modern readers as too apologetic. $C f$. Michael Sugrue, South Carolina College: The Education of an Antebellum Elite (Ph.D., Columbia University, 1992).

One might try to tease out some of the ideas by looking to the catalog of books in the University of Alabama Library. See Richard Furman, Catalogue of the library of the University of Alabama (Tuskaloosa, M. J. Slade, 1837); Wilson G. Richardson, Catalogue of the library of the University of Alabama ... (Tuscaloosa, Printed by M. D. J. Slade, 1848). Guy Hubbs has made an important start in this direction. See Guy Hubbs, "Dissipating the Clouds of Ignorance”: The First University of Alabama Library, 1831 1865, 27 LiBRARIES \& CUlTURE 20-35 (1992) (reconstructing intellectual life based on library catalog). And further work, speculative though it would have to be, might use the catalogs to create a map of the intellectual terrain. It would detail what issues the librarians who collected the books thought might be of interest. While book acquisitions may say more about what books are in circulation than about interests of those acquiring them, they at least illustrate the ideas in circulation. And once we map the terrain, it remains for further scientific and systematic work to refine which parts of the terrain were most often visited and why?

The library catalogs of other colleges will likely provide a useful comparison. See, e.g., CharLEs C. Jewett, A Catalogue of the Library of Brown University, in Providence, Rhode Island (1843). Historians might take some inspiration from Francis Wayland's celebration of the role of books in both the Brown library and the Providence Athenaeum as guides to intellectual development. See Francis Wayland, A Discour SE, DELIVERED at the opening of the Providence Athen aeum, July 11, 1838 (Providence, 1838); Wayland, Discourse on Nicholas Brown. See also Catalogue of the Members and Library of the la fayette Society of La Grange College (Tuscumbia, A.C. Matthews, Franklin Democrat Office, 1844) (cataloging 1158 books in the LaFayette Society's library); Catalogue of the Library, And names of Members of the Philomathesian Society of Kenyon College: From its formation in 1827 to 1840 (Gambier, Ohio, T.R. Raymond, 1840).

23 Edward C. Bullock, "True and False Civilization." an Oration Before the Erosophic and Philom atic Societies of the University of Alabama, on Their Anniversary Occasion, July 13, 1858 at 29 (Tuscaloosa, Independent Monitor, 1858). 
little use has been made of the addresses to the University's literary societies. ${ }^{24}$ The lectures demonstrate both the sophisticated ideas in circulation and the ways that lecturers sought to spread their values. They are also testimony to the rapid growth of thought; several refer to the wilderness of Tuscaloosa and how it was only a few decades removed from the days of first settlement. $^{25}$

\section{Eras of Thought at the University of Alabama}

A. Presidency of Alva Woods, 1831-1837: "We must think for ourselves"

The University's first president, Alva Woods, illustrates an affection for the idea of searching for truth. ${ }^{26}$ Woods was born in Vermont in 1794, then educated at Phillips Academy.

24 For the few citations I have found to the University of Alabama addresses, see Drew Gilpin Faust, The Dilemma of the Intellectual in the Old South at 157 n.25 (1978) (citing William Gilmore Simms, The Social Principle: The True Source of National Permanence. An Oration, Delivered Before the Erosophic Society of the University of Alabama, at its Twelfth Anniversary, December 13, 1842, at 7 (Tuscaloosa, Erosophic Society 1843 )); Rush Welter, The Mind of America, 1820-1860 147 (1975) (citing B. W. Huntington, Individuality. An Address Delivered Before the Philomathic Society of the University of Alabama at its Twelfth Anniversary (Tuskaloosa, M.D.J. Slade, 1845)); James Perrin Warren, Culture of Eloquence: Oratory and Reform in Antebellum America 149 (1999) (citing Simms, supra note 24); O'Brien, supra note 20, at 1245 (same). Indeed, relatively little use has been made of southern literary addresses more generally. The exceptions include Faust, supra note 24, at 155 n.4 (citing John Reuben Thompson, EduCATion ANd Literature In ViRG INIA: An Address Delivered Before the Literary Societies of Washington College, Lexington, Virginia, 18 JunE, 1850 (Richmond: H.K. Ellyson, 1850)); id. at 55-57 (citing James Henry Hammond, South Carolina College Oration (Dec. 4, 1849) (unpublished manuscript, Hammond Papers, Library of Congress); Tucker, An Oration Before the Two Societies of the South Carolina College in the $4^{\text {th }}$ of December 1849, 17 S. Q. REV. 37-48 (1850)); $i d$. at 164 n.28 (citing Tucker, A Discourse on the Dangers That Threaten the Free Institutions of the United States, Being an Address to the Literary Societies of Hampden Sydney College, Virginia ... (Richmond, J.B. Martin, 1847)). Other references to southern college addresses include John McCardell, The Idea of a Southern Nation: Southern Nationalism and Southern Nationalism, 1830-1860 204 (1979) (citing ADDRESS Delivered on Thursday, December 18, 1857, on the OCCASion of the Inauguration of Rev. Robert J. Sant on As President of OAKland College (New Orleans, T. Rea, 1852)). Northern addresses have received more attention. Beyond Emerson's American Scholar and Everett's, see, e.g., Daniel Walker Howe, Political Culture of the American Whigs 86 (1983) (quoting Daniel Barnard, Man And the State: An Address Delivered Before the Connecticut Alpha of Phi Beta Kappa, August 19, 1846 (New Haven, B.L. Hamlen, 1846)); Lawrence Kohl, Politics of Individualism 241 (1988) (citing Barnard, supra).

25 Alexander Brevard Forney, Address delivered before the Society of Alumni of the University of Alabama, on the eighth Anniver SAry of the Society, December 11, 184315 (Tuscaloosa, M.D.J. Slade, 1844) ("Wherever the axe of the woodman has been heard, the school-house and church have been erected.... And in this day, in the very bosom of this wilderness, we are assembled, within the precincts of an institution, dedicated to science and literature."); Walter Henry Crenshaw, An Oration [to the University of Alabama Alumni Society] (Tuscaloosa, Baldwin, 1839) (typescript copy in Hoole Special Collections Library, University of Alabama).

26 Alva Woods, The introductory lecture before the Alabamian Institute, Delivered December 7 , 1833, in the hall of the House of Representatives (Tuscaloosa, Ala. W.W \& F.W. M'Guire 1834); Alva Woods, A eulogy on Lafayette, Delivered at the request of the mayor and alder men of Tuscaloosa, in the presence of members of the Legislature of Alabama and other citizens, Dec. 27,1834 (Tuscaloosa, Ala., Intelligencer and Expositor Office, 1835); Alva Woods, Intellect UAL AND MORAl CUlt URE A Discourse, DELIVERED AT HIS INAUGUR ATION AS PRESIDENT OF TRANSYLVANIA UNIVERSITY, OCTOBER 13TH, 1828 (Lexington, 
He entered Harvard College in 1813, where he graduated in 1817. Following study at Andover Theological Seminary, he returned to Harvard as a tutor in 1819 and finished his studies at Andover in 1821. Following a year teaching at the Columbia College in Washington, Woods joined the faculty of Brown University, which he left in 1828 for the presidency of Transylvania University in Lexington, Kentucky, after which he assumed the presidency of Alabama in March $1831 .^{27}$

Woods' graduation addresses to the University of Alabama reflected common attitudes for a University president at the time: concern for language, morality, and learning. His concluding address in 1837, for instance, had two goals: the preservation of language, which meant the respect for precision in language, and morality. ${ }^{28}$ He stressed the importance of morality to the continuation of the government, ${ }^{29}$ as well as the dangers of too much freedom. ${ }^{30}$ The later portion is drawn largely from William Paley's Moral Philosophy, which Woods used as a text in his moral philosophy class. ${ }^{31}$

Woods' 1836 baccalaureate address centered around the importance of disciplining

Ky., J.G. Norwood 1828). The Inaugural Discourse sees the role of schools in fostering Christianity and intellectual and moral improvement. Several of his shorter and post-war speeches are reprinted in Literary and Theological Addresses, supra note 6, at 211-73, along with excerpts from correspondence with his former students.

27 See Biographical Sketch, in Woods, LiterARy ANd Theological AdDresses, supra note 22, at 377-98. Some hint of Woods' attitudes on slavery appears in his biographical sketch, which mentions slavery as a partial cause of his departure from the University. Id. at 392 ("the never-ceasing and laborious duties of his office, and the debilitating effects of the southern climate on a constitution not entirely acclimate, began seriously to impair the health of Dr. Woods; and this, united with a very earnest desire to educate his son in the free states of the North, induced him to resign the Presidency, and return to the more invigorating climate of New England."). Transylvania University itself underwent substantial transitions over the course of the nineteenth century. See Alfred L. Brophy, Slavery and Antislavery Thought at Transylvania University (unpublished paper).

28 Alva Woods, Valedictory Address Delivered at the Close of the Seventh Collegiate Year of the University of Alabama, December 6, 1837, reprinted in Literary ANd Theological Addresses, supra note 22 , at 211-73. See esp. 237-67 (discussing morals).

29 Id. at 238 ("Even the few restraints imposed by our laws, owe their efficiency entirely to the force of public opinion. When public opinion ceases to sustain the laws, they are as nugatory as if blotted from the statute book.").

$30 \quad I d$. at 238 ("While this freedom is very properly a source of gratulation, it should not render us indifferent to the dangers which lurk around it. A serpent and forbidden fruit were found in the bowers of the first earthly paradise;-and but one Eden was provided for the great progenitor of mankind."). See also id. at 246-47 (discussing excesses of French Revolution); Eulogy on Lafayette, in Woods, AdDRESSES, supra note 22, at 137, 139 ("in order to render eulogies on the dead beneficial to living, these eulogies must speak the language of truth"); id. at 155 ("But these bright dawnings of French freedom, were soon overcast by dark clouds of the most portentous aspect.

Regulated freedom, like the gentle stream of the mountains, which gradually swelling its tide till it becomes a mighty river, sends its fertilizing influences through the distant plains; and in a thousand ways ministers to the welfare of man;-but unrestrained freedom, like the rushing torrent, which breaking away from its banks, and bearing down with it the mountain avalanche, spreads desolation on the plains below, and carries destruction to the abodes of men.").

31 See id. at 92-93 (listing examination in moral philosophy, apparently from 1833, based on Paley's Evidences of Christianity). 
passions, first by children and then by the nation more generally. "Why is our country sometimes disgraced with riotous mobs, trampling on all civil authority, and placing property, and even life itself, at the mercy of unbridled passions? These rioters were never trained up in childhood in the way they should go. They were never taught subordination and self-government."32 Like many other orators, Woods saw virtue in the United States' changes, such as making religion more simple and accessible than in Europe and in making government more receptive to the people's will. But he wondered whether "we are in no danger of passing from the extreme of blind submission to the opposite extreme of universal resistance?"33

Woods' concern for the excesses of democracy appear in fullest form in his lecture at the inauguration of the Tuscaloosa Lyceum. The Lyceum offers the hope of elevating the masses, not depressing the eminent:

The institution is altogether republican in character, and democratic in its tendencies.

Here all the monopolies purchased by wealth, and all the distinctions acquired by power and rank, disappear and are forgotten. Here is the true doctrine of equality which consists in elevating the whole mass of the community. It is a leveling upwards, and not downwards. . . . Enlighten the people with whom all physical and political power resides. Let them be well informed, and their minds well disciplined, and you need fear no disturbance of the public tranquillity, no laws ruinous to property, no disgraceful riots, and outrages, no impairing the faith of contracts, no destruction of public credit. ${ }^{34}$ James Birney, who had some responsibility for hiring the University's first president and faculty, brought Woods and the young professor and anti-slavery activist Henry Tutwiler to Alabama. Birney's role in shaping the University's early years has been left unexplored by the University's historians, though it is important. ${ }^{35}$ Birney, who in 1844 ran for President of the United States on the Liberty Party, was working assiduously in Alabama on behalf of the American Colonization Society beginning in the late 1820 s. Already Birney was working to bring Enlightenment ideas to the University and to the state. Those Enlightenment ideas meant a belief in equality, freedom, and the role of reason and science in human progress. ${ }^{36}$ Birney was remarkably unsuccessful; by the mid-1830s, his spirit was broken and he left for Ohio and a later career as a radical abolitionist politician.

\footnotetext{
32 Alva Woods, Baccalaureate Address Delivered at the Fifth Annual Commencement of the University of AlabAma, December 17, 1836 in Woods, supra note 22, at 191,194. See also id. at 193 (“A family contains the rudiments of an empire;-and the paternal authority and the order of domestic life, supply the foundation of civil government. It is, then, in the family circle that the character of a nation is formed. It is around the hearth and home of infancy that the youth and manhood of future years are molded.").

$33 \quad$ Id. at 195.

34 Woods, Lyceum, in id. at 56-57.

35 See Sellers, History of the University of Alabama, supra note 22, at __ (mentioning Birney's role in hiring faculty, but not linking Birney's actions to the ideology of the faculty).

36 See, e.g., Henry F. May, The Enlightenment in America (1976); Gertrude Himmelfarb, The Roads to Modernity: The British, French, and American Enlightenments (2004).
} 
During Tutwiler's tenure at the University, he represented well Birney's aspirations for a University built around Enlightenment ideas. Tutwiler, born in 1807 in Harrisonburg, Virginia, graduated from the University of Virginia in 1829. He worked with Birney in advocating the antislavery cause in Tuscaloosa through the American Colonization Society. As Tutwiler wrote to Birney in 1832, "almost all moral and political evil in this state may be traced to this fruitful source [slavery]-it exhausts our soil, corrupts our morals, and is the chief cause of that diversity of interest which is fast tending to rend asunder our political fabric." ${ }^{37}$ More than thirty Tuscaloosa residents supported the ACS in $1828 .{ }^{38}$ He then taught mathematics at the University of Alabama from its opening in 1831 until 1837. Then he taught at La Grange College from 1837 to 1847; after that he had his own school in Greene Springs, Alabama. ${ }^{39}$

Tutwiler's 1834 oration, given at the beginning of the school year in August, is the longest extant statement of his ideas. It is an optimistic assessment of humans' ability to make moral progress. Humans have the desire for progress in knowledge and take pleasure in it. His address represents the Enlightenment thought that was still dominant in parts of Virginia in the 1810 s and 1820s of Tutwiler's youth. ${ }^{40}$ While acknowledging throughout the role of God, the address begins with an emphasis on reason, as informed by (but not replaced by) sentiment. Where many antebellum moral philosophers placed common sense philosophy at the center of their thought, Tutwiler went beyond them. He admitted a role for sentiment in addition to reason. He urged students to work assiduously to develop their intellect. "Would you, for inglorious ease," Tutwiler asked, "resign your birthright to all the lofty pleasures of knowledge?" 41 Tutwiler's address represents the idea that the search for truth sets scholars on lonely paths, which may lead them to ask unsettling questions about the world around them.

That questioning of the world around them was all part of learning. There had to be personal effort and reflection. "We must think for ourselves, and not be the mere passive receptacles of the thoughts of others." That independence of thought, which represents a the role of Enlightenment over tradition, allows a student to grow. One example of the need for independence and questioning appears among readers of books:

37 Tutwiler to Birney (August 20, 1832), 1 Letters of James G. Birney 17 (Dwight L. Dummond ed.).

38 Quist, Restless Visionaries, supra note 22, at 315-17, 323-25. Quist provides a study of the social and economic bases, which links into the ideas in the orations. See also Robert Eno Hunt, Organizing a New South: Education Reformers in Antebellum Alabama, 1840-1860 (Ph.D. dissertation, University of Minnesota, 1988).

394 Thomas McAdory Owen, History of Alabama and Dictionary of Alabama Biography at 1694-95 (1921).

40 See, e.g., Drew McCoy, The Last of the Fathers: James Madison and the Republican Legacy (1989) (discussing Virginia thought through Madison's death in 1834).

41 Henry Tutwiler, Address Delivered Before the Erosophic Society at the University of Alabama, August 9, 1834 at 8 (Tuscaloosa, Ala., Robinson \& Davenport, 1834). Tutwiler refers to the work of radical Lord Broughman, which may suggest some of Tutwiler's views about the possibilities of education and the relationship to knowledge to progress. See id. at 8 (citing Broughman, Pursuit of Knowledge under Difficulties).

42 Id. at 11 . 
Books have become one of the most important sources of information; but they may be, and no doubt often are, productive of evil instead of good-. . . so unreflecting persons . . . are disposed to believe every thing which they read, when it does not conflict with a previously formed opinion. Now to read any book and adopt what is in it as mere matter of authority, will not only lead to confirmed ignorance, but it positively hurtful to the mind. ${ }^{43}$

It is an optimistic address, concluding with a celebration of moral progress and one is not surprised to learn that Tutwiler opposed slavery.

Many of the addresses during Alva Wood's tenure were given by University of Alabama faculty, such as Alva Woods, Henry Tutwiler, R.T. Brumby, ${ }^{44}$ and Henry W. Hilliard, ${ }^{45}$ as well as by younger, promising Alabamians, such as Frederick Beck ${ }^{46}$ and Benjamin Porter, who had recently joined the Alabama legislature. ${ }^{47}$ They followed in many ways the theme established by Professor Tutwiler: an exploration of the virtues of scholarship, of a search for truth, and an independence from social norms. They are optimistic addresses, linked to the world of the early national period, with its optimistic assessment of the steady progress in technology and morality. Henry Hilliard's 1832 address was typical of literary addresses from the 1820 s and early $1830 \mathrm{~s}$ in exploring the influence of America on the literary mind. ${ }^{48}$ Hilliard, like Tutwiler

$43 \quad$ Id. at 11-12.

44 See R. T. Brumby, Anniversary address, Read before the Philomathic Society of the University of Alabama, December Eighth, 1838 (Marmaduke J. Slade, Tuskaloosa 1838); R. T. Brumby, An or Ation Delivered before the Erosophic Society of the University of Alabama, August 10, 1833 (Tuscaloosa, Ala., W.W. \& F.W. M'Guire, 1833). Brumby published frequently on lectures and on his geological surveys. See, e.g., R. T. Brumby, Report of the Committee on Education in relation to the University of Alabama. (Tuscaloosa, Intelligencer Officer, 1836); R. T. BRUMBY, AN ORATION ON MAN, CONSIDERED AS A SOCIAL BEING, WITH THE ANNiversary address to the Euphradian Society, Delivered in the CH Apel of the South Carolina College, on the 18 th December, 1823 ... Published by order of the Society (Columbia, [S.C.] Telescope Office, 1824). He was also editor of the States Rights Expositor and Spirit of the Age in 1832 and 1833 in Tuscaloosa.

45 Henry W. Hilliard, An Address Delivered Before the Erosophic Society, at its First Anniversary, MAy 26, 1832 (Tuscaloosa, Ala., Wiley, M'guire and Henry, 1832).

46 Franklin K. Beck, an Address Delivered Before the Graduating Members of the Erosophic Society of the University of Alabama, at its Third Annual Commencement August 8, 1835 (Tuscaloosa, Ala., Meek \& McGuire, 1835). Beck was born in 1814 in Duplin County, North Carolina and matriculated at the University of Alabama, although he graduated from Georgetown College in Washington, D.C. He studied law at Yale in 1837 and began law practice in Alabama in 1841. 3 OWEN, supra note 39, at 120.

47 Benjamin F. Porter, Address Delivered Before the Philomathic Society of the University of Alabama, on the OcCasion of its Fourth Anniversary (Tuskaloosa [Ala.], 1836).

48 See, e.g., C. J. Ingersoll, A Discourse concerning the Influence of America on the Mind, Being the Annual Oration delivered before the American Philosophical Society, at the. University in Philadelphia, October 18, 1823. (Philadelphia, A. Small, 1824); William Ellery Channing; Remarks on National Literature (1830); Edward Everett. See also Ronald F. Reid, Edward Everett: Unionist Orator 26-27 (1990) (discussing Everett's literary addresses). 
educated at the University of Virginia, spoke on the "literary prospects of our country." Hilliard, who trained as a lawyer in Georgia after graduating from South Carolina College in 1826, and later served in the United States House o fRepresentatives as a moderate Whig, celebrated the triumph of moral and intellectual progress. "The conquest of the mind has begun-the dark day of blood has departed-the sun of peace hath arisen. . . . The empire of the mind is established, and henceforth nations are to be ranked, not according to their physical, but their moral strength."49 He credited the United States' government for the progress. A government "disposes not alone of property and life, but it controls the intellect." ${ }^{50}$ He located several intellectual forces leading to literary achievement-the United States' government, our distance (and therefore insulation) from Europe, and Christianity. He saw a divine mission in the United States. "Who," he asked, "does not rejoice that God has cast his lot on this land, in behalf of whose liberty, Nature herself does battle?"51 The University and the state of Alabama both confirmed that optimistic, nationalistic vision:

What a beautiful illustration does our own State present of the excellence of that system under which we live! Over its fertile lands there is spread out already, an intelligent, noble and rapidly increasing population. It seems as if but yesterday, this spot was a wilderness; the forest of centuries waved over it; the only contrast to its unbroken gloom and stillness was the glare of the council fire, and the wild song of the Indian. Today, however different a scene! Beauty and art, and elegance and fashion. Here is a LITERARY INSTITUTION! 52

R.T. Brumby's 1833 oration, delivered the next year, is more narrowly focused, but similarly optimistic. It celebrates the role of science. A series of inventions-Perkins' nail machine, Whitney's cotton gin, Franklin's lightening rod, Fulton's steamboat, Treadwell's steam-press-illustrated the role of science in greatness. ${ }^{53}$ Knowledge broke the hold of superstition in human minds. ${ }^{54}$ And knowledge broke the hold of tyranny too. Brumby gave a

49 Hilliard, supra note 45 , at 4.

$50 \quad$ Id. at 5.

$51 \quad$ Id. at 13 .

52 Id. at 10 .

53 Brumby, Erosophic Society, supra note 44, at 5. Richard Trapier Brumby was born in South Carolina in 1804 and graduated from South Carolina College in 1824. He taught at the University of Alabama from 1834 until 1849 , then joined the faculty at South Carolina College, where he was educated. See 3 Owen, supra note 39 , at 240. In South Carolina he published several articles, including Foot-Prints of the Creator, or the Asterolepis of Stromness, 5 S. Presbyterian Rev. 111 (1851); Evidence of the Degradation of Animals, 5 S. PRESBYTERIAN REV. 417 (1852); R. T. Brumby, An AdDress on the Sphere, Interest ANd IMportance of GeOlogy. Delivered December 8, 1849... (Columbia, S.C., 1849). He died in 1875 in California. He seems, like much of the antebellum South, to have become more conservative in the $1840 \mathrm{~s}$ and $1850 \mathrm{~s}$.

54 Id. at 7. Brumby's Erosophic Society oration follows a motif common at the time, of celebration of the role of science and progress. It is quite similar, for instance, to S. Henry Dickson's address to the Yale Phi Beta Kappa Society. See S. Henry Dickson, An Oration Delivered at New Haven, Before the Phi Beta Kappa Society, 
remarkable talk, which would be impossible at Alabama fifteen years later. For he praised the printing press as putting into "the hands of the friends of the rights of man, intelligence." 55 The allusion to Thomas Paine's Rights of Man is astounding, and it is a hint of radicalism still sometimes appearing as late as the $1830 \mathrm{~s}$. Brumby went on to celebrate the demolition of monarchy during the French Revolution, a position at odds with addresses from the 1840s through the Civil War. ${ }^{56}$ Brumby's 1838 address, delivered shortly after Basil Manly became president of the University, similarly centered on moral uplift. He was concerned with the state's failure to adequately fund education and he presented a simple plan for funding. "All intelligent men now concur ... that the present improved condition of the earth, compared with all former periods, must be ascribed to the correction of the heart, and the illumination of the mind of man; - in a word, to the increased perfection of his moral character." 57

Benjamin F. Porter's 1836 address to the Philomathic Society opposed capital punishment. Porter was born in Charleston, South Carolina in 1808 and then studied medicine and read law. He moved to Alabama around 1829 and entered the legislature, in 1832. Porter subsequently became the reporter for the Alabama Supreme Court. ${ }^{58}$ He offered the address because, though the subject of capital punishment "may properly be the concern of the Legislator," he found that "from these halls, the abode of letters and of science, are to issue forth lawgivers and statesmen, who in succeeding years are to become the benefactors and protectors of mankind. ${ }^{, 59}$ It is a surprising address, because he argues against capital punishment on

August 17, 18426 (B.L. Hamlen, New Haven 1842) ("many generations have passed away since the witch mania of Europe added an unimaginable gloom to the decrepitude of old age, and made gray hairs no longer venerable tokens of sage experience, but signals of fiendish malignity and unholy associations. And still more recently in our own bright land, the same dark insanity of excited ignorance spread for a time its blighting influences, consigning to torture and to death the old and the young, the parent and the child, the pastor and his flock. It was reserved for the schoolmaster to release mankind from this horrible bondage. The increasing light of natural science has reached even these dark corners, and witchcraft, spectres, and magical delusion, have yielded to the discoveries of chemistry and the laws of optics. Hibbert, and Scott, and Brewster, have broken the conjuror's wand, and laid every unquiet ghost in eternal repose. Who will say that we are not better and happier for this liberation? The school-boy crosses the church-yard in his nightly path homeward, exempt from the chill trembling which shook the limbs of his sturdy grandfather; the gay young bride fears no longer the secret curse of hatred or the evil eye of envy, falling upon her with fatal blight when she leaves the arms of her parents for the new home of her husband; the decrepid mother of the village need not now lament that the years and infirmities which render her an object of compassion and charity, should convert her, instead, into a strange compound of imbecility and superhuman power, and surround her with awe and terror, taunts and bloody cruelty.").

$55 \quad$ Id. at 16 .

$56 \quad$ Id. at $16-17$.

57 Brumby, Philomathic Society, supra note 44, at 6. His address is mentioned in Tuscaloosa's short-lived literary magazine, 1 Southron 64 (1839).

58 See Paul M. Pruitt, An Antebellum Law Reformer: Passages in the Life of Benjamin F. Porter, 11 GULF STATES Historical Rev. 22-58 (1995).

59 PORTER, supra note 11 , at 6. 
grounds of expediency and morality. He saw capital punishment as based on feelings of revenge. But in a state of society, he saw the need for restraints on power and on revenge. Punishment, in his view, should be based on the protection of society by positive examples. "The conception of justice of a well regulated community," Porter said in typical Whig fashion, is "of a firm, moderate, and merciful tribunal-regulating by collective wisdom the affairs of mankind, and opposing to their natural frailties the equal restraints of law, justice, and virtue."

In keeping with other schools, there was anti-slavery sentiment at Alabama during the early 1830s, although it is difficult to assess its extent. William Gaston's Address Delivered Before the Dialectic and Philanthropic Societies at Chapel Hill, N.C., June 20, 1832, advocated anti-slavery. ${ }^{61}$ We should be cautious in attributing too much radicalism to Gaston, however. When he spoke at Princeton in 1835, he was spoke in favor of law against radicalism. ${ }^{62}$

With the departure of President Alva Woods in1837, the character of the addresses began to change. The conventional story of Woods' departure is that he was too strict and the students rebelled, causing a virtual shut-down of the University. ${ }^{63}$ The conventional story has no account of the battle over slavery and moral philosophy that appears to have swirled around Tuscaloosa in the mid-1830s, hints of which appear in Woods' reflections at the end of his life.

B. Presidency of Basil Manly, 1837-1855: "Men [and Women] of the Mind"

The middle 1830s were a period of division in the antebellum South, of paths not taken and options foreclosed. In 1831, Nat Turner's rebellion caused Virginians to seriously rethink slavery. When the Virginia legislature emerged from those debates in 1832, the commonwealth was more seriously committed to slavery than it had been before the rebellion and far less willing to abide antislavery talk. Thomas Roderick Dew5 of William and Mary contributed a pamphlet to the debate, which became one of the most important proslavery arguments in the years leading into the war. ${ }^{64}$ In 1835 Charleston faced a crisis of abolitionist literature distributed through the United States mails. As happened in communities throughout the south, Tuscaloosa responded to the threat of abolitionist literature. The Tuscaloosa county grand jury indicted an editor in New York City. Talk of gradual abolition through the American Colonization Society declined and shortly thereafter Birney left Alabama.

In 1837, the year that Ralph Waldo Emerson delivered his "American Scholar Address," the University of Alabama switched presidents. In place of the Rhode Island Baptist Alva

\footnotetext{
60 Id. at $12-13$.

61 discussed in Clement Eaton, Freedom of Thought Struggle 200 (1940).

62 William Gaston, an Address Delivered Before the American Whig and Cliosophic Societies of the College of New Jersey September, 29, 1835 (John Bogart, Princeton, 1835).

63 See SELLERS, supra note 45 , at

64 Originally printed as Thomas R. Dew, Abolition of Negro Slavery, 12 AM. Q. REV. 189-265 (Sept., 1832), it was printed in expanded form as Thomas R. Dew, Review of the Debate in the Virginia Legislature, 1831-32 (Richmond, 1832). The essay Abolition of Negro Slavery is conveniently available in abridged form in THE Ideology of Slavery: Proslavery Thought in the Antebellum South, 1830-1860, supra note 24, at 21-77.
} 
Woods came South Carolina Baptist minister Basil Manly. ${ }^{65}$ Manly set about changing the nature of the University. ${ }^{66}$ When Manly arrived, Tutwiler left and with him so did the active antislavery movement at the University, at least so far as can be determined from the nowexisting records. Manly set about building the University by hiring more faculty, including Yale educated science professor Frederick A.P. Barnard. Barnard arrived in 1839; shortly there developed a conflict between Manly and Barnard. The conflict included Manly's charge that Barnard was antislavery, even thought Barnard spoke in favor of slavery. ${ }^{67}$

The first literary address delivered at the University under Manly's tenure was Brumby's, so there was some continuity with the practices under President Woods. The next was an address by William Crenshaw; it likewise reflects the optimism of Brumby and other orations that education leads to progress, a proposition with which most antebellum Americans agreed, even if in varying degrees. However, soon the character of the addresses began to change.

Alexander Meek's 1839 oration, "The Southwest: Its History, Character, and Prospects," illustrates Tuscaloosa literary culture well, as well as the understanding of Alabamians toward their history. Meek, who was born in 1814 in South Carolina and graduated from the University

65 Fuller, supra note 22, at 127-29. For more on the Manly's proslavery thought see his lecture to the Tuscaloosa Lyceum, Lecture on the Bees, Manly Family Papers, Hoole Library, University of Alabama.

The comparison of Woods and Manly suggests another comparison: that of Rhode Island Baptist Francis Wayland to South Carolina Baptist Richard Fuller. Wayland and Fuller debated slavery in the 1845 book Domestic Slavery Considered as a Scriptural Institution: In a Correspondence between the Rev. Richard Fuller of Beaufort, S. C., and the Rev. Francis Wayland, of Providence, R. I. (New York, L. Colby; Boston, Gould, Kendall and Lincoln, 1845).

66 See Fuller, supra note 6, at _ ; Address of His Excellency Governor Bagby, When Inducting Into Office the President of the University of Alabama; Together with the Address of the President, Rev. Basil Manly. Delivered in the Rotunda, on Commencement Day, December 6, 1837 (Tuscaloosa, Ala., Ferguson \& Eaton, Printers, 1838); Basil Manly, Address at Commencement, University of Alabama, December 12, 1838, reprinted in 5 Bulletin of The Marion Institute 16 (1908), available in Manly Family Papers, Box 6 (also identified as Box 397), Hoole Special Collections, University of Alabama.

67 Fuller, supra note 22, at 170-73. Some of the conflict between Manly and Barnard was attributable to their differing educational philosophies. The nature of that conflict is inferable from Manly's 1854 address and Barnard's 1854 address. See Frederick A. P. Barnard, Improvements Practicable in American colleges: A PAPer REAd Before the American association for the AdVAncement of EduCATion, at its fifth annual SeSSiOn, in the Chapel of the University of New York, on the 30th of August, 1855 (1856 Hartford : F.C. Brownell); Frederick A P Barnard, Letters on college government, and the eVils inseparable From the AmERicAn COllege System in its Present form (New York, D. Appleton \& Co. 1855); Frederick A P Barnard, Analytic GRAmm AR, with Symbolic illustration (New York, E. French, 1836).

See also Record of the Testimony and Proceedings in the Matter of the Investigation by the Trustees of the University of Mississippi, on the $1^{\mathrm{st}}$ And $2^{\mathrm{ND}}$ OF MarCh, 1860 , of the Charges Made By H.R. Branham, Against the Chancellor of the University (Mississippian Office, Jackson, 1860) (detailing the trial of F.A.P. Barnard by the University of Mississippi's board of trustees for using testimony of a slave against a student accused of sexual abuse of the slave). 
of Alabama in 1833, is best known for his literary work, especially the poem Red Eagle, ${ }^{68}$ and his literary criticism. ${ }^{69}$ He deserves even more attention than he has received, for his short-lived literary journal, Southron, was important. Some measure of his attitude comes from its first issue, which published a proslavery essay; a review of William Gilmore Simms' novel Richard Hurdis. Southron shows Tuscaloosa to have been well-connected to larger intellectual movements. After graduation from Alabama, he became a lawyer and was soon to become attorney general.

The 1839 oration was a part of M'eek's history of the southwest, published in $1854 .^{70}$ Part of the purpose was to "dissipate the ignorance" of history of the Southwest, particularly the mixture of native, Spanish, French, and English cultures. For he invoked Lord Bolingbroke's statement that "history is philosophy teaching by example." "11 Meek's history, then, was directed toward an understanding of the "Moral and Intellectual Character of the Southwest." 72 For, as he told the students, "even a superficial notice of the history of the human race, shows us that man, in his intellectual and moral attributes, is ever modified by the circumstances around him." Meek thus presented a subtle understanding of the relationship between laws and manners (what we might call custom). ${ }^{74}$ Meek's discussion of law and custom, expressed by many jurists as well as orators, are part of a world of jurisprudence that sought to fit judicial decisions and statutes to the American character. Judges and legislators sought to reflect and to shape that

68 A. B. Meek, The Red Eagle. A poem of the South (New York, D. Appleton \& Co., 1855); A. B. Meek, Songs and poems of the South (Mobile, S.H. Goetzel \& Co., 1857); A. B. Meek, A poem, Pronounced before the Ciceronian club and other citizens of Tuscaloosa, Alabama, July 4, 1838 (Tuscaloosa [Ala.], The Ciceronian Club 1838); 4 Owen, supra note 39, at 1183.

69 See A. B. Meek, Americanism in literature. An oration before the Phi Kappa and Demosthenian Societies of the University of Georgia, at Athens, August 8, 1844 (Charleston, Burges and James 1844), reprinted in Meek, Romantic Passages, supra note 70, at 107; A. B. Meek, JaCK-CAdeism And the Fine Arts: A discour se before the liter ary societies of La Grange College, Alabama, June 16, 1841 (Tuscaloosa, M.D.J. Slade, 1841), reprinted in MeEk, Romantic PAssages, supra note 70, at 145, 150 ("Any one, who will cast an observant eye upon the pursuits of our people, will find how deeply this spirit of utilitarianism, as by courtesy of sepeech it is called, is ingrained in the very constitution of our society. ... The great study of the farmer, the lawyer, the physician, the merchant, the mechanic, is how to double his profits.").

70 A.B. Meek, The Southwest; Its History, Character, and Prospects: An Oration Before the Erosophic Society of the University of Alabama, December 7, 1839, in A. B. MeEk, ROMANTIC PASSAges IN SOUTHWESTERN HISTORY; inCLUDing ORATIONS, SKetChes, AND ESSAYs 11 (New York, Mobile, S.H. Goetzel \& co., 1857).

$71 \quad$ Id. at 22 .

72 Id. at 48 .

$73 \quad$ Id. at 49 .

74 One extended connection of law and custom appears in Thomas R. Dew's history of western civilization, The Laws, Customs, and Manners of Ancient and Modern Nations, supra note 2. Michael O'Brien's subtle reading of Dew appears in 2 O'Brien, supra note 5, at 606-21. 
character. $^{75}$

From his study of the southwest, Meek concluded that the people of Alabama were pragmatic businessmen. They had a series of traits: frugality, economy, honesty, hospitality, selfreliance. But they also had less positive traits: rough manner, violent nature, disrespect for law. Overall, those characters lent a stability and vigor to the political culture. "Domestic in their dispositions, firm and patriotic, they are not wafted about by those excitements in politics and trade, which have so often lashed into tempest the crowded and fevered populations of Manchester and Paris."76 The address showed the gradual progression of Anglo-Saxons in Alabama and the triumph of liberty for whites. It was a celebration of local history, almost a form of hagiography, which left the listeners with an appreciation for their own distinctive culture. Slavery, of course, was part of that culture; in fact, "much of that character which is peculiar to our section of the Union is traceable to this institution." He found "that it is an Institution, in itself, naturally, morally, and politically right and beneficial." Slavery, quite, simply, "generated, upon the part of our white inhabitants, a spirit of superiority and self-esteem, a certain aristocracy of feeling, and a proud chivalry of character." That superiority was part of a spirit of republicanism, of seeming equality among white men. And slavery produced other benefits as well, like the ability of white men to devote more time to "intellectual improvement." the operation of this institution upon our unparalleled natural advantages, we shall be the richest

\footnotetext{
75 Antebellum jurisprudence is largely ignored by American legal historians. See, e.g, David M. Rabban, The Historiography of Late Nineteenth-century American Legal History, 4 THEORETICAL INQUIRIES L. 541 (2003) (beginning story with Gilded Age). There are, however, several places where it has received important attention. In small parts by Morton Horwitz and those who question his findings. And in greater depth by those writing on the Fugitive Slave Act of 1850. See, e.g., Anthony Sebok, Judging the Fugitive Slave Acts, 100 YALE L.J. 1835 (1991); Robert Cover, Justice Accused: Antislavery and the Judicial Process (1975). Though in the case of the Fugitive Slave Act, the rich debate over duty to law and the harm that came to law when it was not respected, has yet to be fully described and analyzed. See, e.g., Timothy Walker, The Reform Spirit of the Day: An Oration Before the Phi Beta Kappa Society of Harvard University, July 15, 1850 (Boston, James Munroe \& Company 1850); Daniel Lord, On the Extra-Professional Influence of Lawyers and Ministers: An Oration Delivered at New Haven, Before the Phi Beta Kappa Society of Yale College ... July 30 , 1851(New York, S.S. Chatterton 1851). For a sample of the debate in Congress, see Senator Rhett, Cong. GlobE, 31st Cong., 2nd Sess., 317 (Feb. 24, 1851) ("A law to have its practical effect must move in harmony with the opinions and feelings of the community where it is to operate.”); Senator Berrien, Cong. Globe, 31st Cong., 2nd Sess., 314 (Feb. 24, 1851) (“[T]he object of that [President's] proclamation . . . is to enjoin upon the ministerial officers of the Government, and upon citizens generally, their obligations to aid in the execution and enforcement of this law. ... It is its moral influence in the community which I think is principally to be relied upon, and which imparts to it its chief importance and value. It will exert this influence, unless fanaticism has extinguished the feeling of patriotism.”); Senator Winthrop, Cong. Globe, 31st Cong., 1st Sess., 1588 (Aug. 19, 1850) (“[A]11 laws depend for their execution and efficiency, in no small degree, upon the opinion of the community that they are just and reas onable laws; and that if this law should go forth to the people of any of the free States with an idea that it is arbitrary, oppressive, and regardless of the great principles of justice, it would be much less likely to be faithfully executed than if it was more in conformity with the public sentiment of those States.").

76 MEEK, supra note 70 , at 57.

77 Id. at 60 .
} 
people beneath the bend of the rainbow, and then the arts and the sciences, which always follow in the train of wealth, will flourish to an extent hitherto unknown on this side of the Atlantic." $" 78$

Thomas Newton Wood's July 4, 1840 address to the two literary societies celebrated the rise of freedom; it catalogued infringements on liberty by the English and the efforts to preserve it by the Swiss. It also looked to a better future, to endeavor "to say something which will tempt reason abroad, or awake to useful action dormant reflection." of Enlightenment: "We celebrate the triumph of mind-the triumph of man's civil and intellectual independence." 80

Issac Hayne's December 1840 address to the combined literary societies dealt with the formation of "individual character." 11 Hayne was skeptical of other orators who saw unbounded upward progress. "I fear, that if this inquiry be made in a spirit of candor, the much vaunted 'march of intellect' and improvement, especially in our own country, which is claimed as illustrating the age we live in, will not be found altogether such as it is represented by anniversary orators, sophomore philosophers, and designing politicians." "It is true, that in much for which the age is considered most admirable, our country stands deservedly preeminent. In commercial enterprises, mechanical ingenuity, and the exercise of all those faculties, whatever they be, which best fit for acquiring wealth-the crowning glory of this age-she had few to compete with, none to excel her." 83 Hayne did not see the similar advances in morals that he saw in technology. For the "spirit of the age" was "characterized by an eagerness for gain, unparalleled in the history of the world-unless, perhaps, that antediluvian race were our equals, whom a just God in his anger swept from the face of the earth." ${ }^{\prime 4}$ He asked rhetorically, "When a monkey is god, what must be the worshipers?"

Hayne promoted different values from other orators. He focused on belief in human virtue, and noble daring action. It was an address aimed not just at thinking and reading, but at action as well. Toward the end, he asked what should students do. "Are you to yield tamely to the current, and helplessly float into whatever stygian pool it may chance to carry you?" Hayne urged his students that "the individual must not only think rightly, but he must form a habit of

\footnotetext{
78 Id. at 60. We get a sense of Meek's goals for history-as celebration-in his oration on the Alabama Historical Society. See Claims and Characteristics of Alabama History: An Oration Before the Historical Society of Alabama, at its Anniversary, July 9, 1855, reprinted in MeEк, Romantic PASSAGES, supra note 70, at 71.

79 Thomas Newton Wood, an Address Delivered Before the Two Literary Societies of the University of Alabama, in the Rotunda, July 4th, 18405 (Tuskaloosa, M.D.J. Slade, 1840).

$80 \quad$ Id. at 6.

81 ISAAC W. HAYNE, ANNIVERSARY ADDRESS ON THE FORMATION OF INDIVIDUAL CHARACTER, AND THE CAUSES Which influence it; Delivered before the Erosophic Society of the University of Alabama, December 12 , 1840 (Tuskaloosa, Hale and Phelan 1841).

$82 \quad I d$. at $4-5$.

$83 \quad$ Id. at 5 .

$84 \quad I d$
} 
acting rightly, and feeling rightly." ${ }^{85}$ Hayne recommended a series of books in ancient literature, such as descriptions of Pericles, Spartan discipline, Thebes, and Cato; in philosophy, he recommended the work of Edmund Burke and Adam Smith's Theory of Moral Sentiments, Edward Bulwer and Walter Scott.

But even as there was celebration, there was fear for the future. Several addresses, like that by Wood, explored literary culture in a manner similar to many addresses at other schools in the 1830s and 1840s. Reverend William T. Hamilton's 1841 Address on the Importance of Knowledge, is a classic exploration of the multiple ways that scientific knowledge has advanced and the special place that Americans thought their society held. Hamilton was born in 1796 in England. He emigrated to Pennsylvania and taught school in Philadelphia in the middle 1810s, while studying for the ministry. He served as a Presbyterian minister from 1824 to 1834 in New Jersey, then moved to Mobile about 1834 as minister. ${ }^{86}$ Scientific advances elevate morals. What distinguished Hamilton from many other optimistic orators was his comparison with other societies in North America. Hamilton contrasted the "wandering hordes of western red men" with their "wretched hurds, their filthy habits, their degenerated morals, their fierce passions, and their weak but cruel superstitions" with the "well ordered community peopling the . . vast regions of our happy States!"87 Institutions that lead to the advance of science were themselves honorable. ${ }^{88}$ Ignorance posed much danger.

But even as the addresses were drawing upon the same themes as those at schools throughout the nation, they were changing in subtle ways. ${ }^{89}$ One might contrast Hamilton's optimistic address, with John Cochran's "Address on the Evidences of Decline in the American Government," delivered to the Philomathic Society on the same day as Hamilton's address to the

$85 \quad I d$. at 10 .

863 OWEN, supra note 39, at 735-36. Hamilton died in 1884.

87 William T. Hamilton, Address on the Importance of Knowledge; Delivered Before the Erosophic Society of the University of Alabama, at Tuscaloosa, December $11 \mathrm{Th}, 1841$ (Tuscaloosa, Ala., Independent Monitor, 1841). See also William T. Hamilton, The duties of masters and slaves respectively, or, Domestic Servitude as SAnctioned by the Bible: A discourse Delivered in the Government Street Church, Mobile, Ala. (Mobile, F. H. Brooks, 1845) ("These ultra abolitionists are few, but they are resolute and reckless. With some of this class it was my lot, during my late tour at North and East, to come into contact; and my deliberate opinion that they are crazy quod hoc. They are monomaniacs; laboring, upon one subject, under a delusion which renders their minds impervious to reason.”); WILLIAM T. HAMILTON, A PLEA FOR THE LiBERAL Education of Woman an Address Delivered at the Annual Examination of the Female Seminary, under the Direction of Rev. S.R. Wright ... at Marion, Perry Co., Ala., July 17th, 1845 (New York, J.F. Trow, $1845)$.

88 HAMILTON, supra note 87 , at 15.

89 See generally Alfred L. Brophy, The Idea of Law in Antebellum Literary Addresses (paper presented at UCLA Law School, Legal Histork Workshop, March 2005). 
Erosophic Society. ${ }^{90}$ Born in Tennessee in the early nineteenth century, he was educated at Greenville College and began the practice of law in 1835 in Jacksonville, Alabama. In 1839 he was elected to Alabama legislature from Calhoun County, then ran and was defeated for Congress by Henry W. Hilliard in $1845 .{ }^{91}$

Cochran had, indeed, a sober message, which counter-acted the optimistic addresses generally given to the literary societies. "By some it may be thought more patriotic to listen only to the syren that chants the eternity of our institutions: but it is the part of masculine patriotism, while it rejoices in the music of hope, to be warned by the raven that occasionally croaks the fatal termination of the last effort of freedom to dwell among men."92 Cochran cited debtor relief and support for the poor, as well as an excess of democracy in the 1840 presidential election, which was won by the Whig candidates William Henry Harrison and John Tyler. "When the Roman people first neglected their own fields as a means of individual support and looked to the public granaries alone, the sun of Roman glory at that moment at its zenith, was seen to go down along the Italian sky, gilding with its expiring flashes those broken monuments of human grandeur, from which at last, in sorrow and darkness, it hid its face forever." 93 There was a lesson here, for Cochran's listeners. They had to choose a path of upright, modest democracy or of pandering to the people. "Decide then, if you will choose the fame of the good man, which even in failure and adversity, challenges the admiration due to the heaven inspired impulse of lofty endeavor, and whose brilliancy is like that of the rocket as it dashes blazing and sparkling to the sky, and exhausts itself in an effort to reach Heaven; or the fame of the bad man, whose brilliancy is like the dim light of the meteor that gleams on the pathway of its own downfall, and flickers and dies in bogs and quagmires." 94

Alexander Gates' July 4, 1841 address to the combined literary societies expressed fear for the future. He recognized, as had Alexander Meek, that societies had differing needs based on their systems of government. ${ }^{95}$ For example, the United States was well-suited to democracy. Other governments were not. Like Meek, Gates also understood the connections between law and morals. "Why is it," he asked, "that we can so readily determine something of the manners, customs, and habits of a people, by an examination of the laws and institutions which govern them as such? Is it that the laws give character to the people, or that the people give character to

\footnotetext{
90 John Cochran, an Address on the Evidences of Decline in the American Government; Delivered Before the Philomathic Society of the University of Alabama, December 11, 1841 (Tuscaloosa, Independent Monitor, 1841).

913 OWEN, supra note 39, at 360 .

$92 \quad I d$. at 5.

$93 \quad$ Id. at 9.

$94 \quad I d$. at 14.

95 Alexander R. Gates, An oration on the anniversary of American independence; Delivered Before the two literary societies of the University of Alabama 12 (Tuscaloosa, Al., The Erosophic Society, 1841). See also MEEK, supra note 16.
} 
their laws?" 96 Yes was the answer on both counts. Gates represented the common belief of southern political philosophers that not all people were suited to freedom. This was part of a belief that people and nations were different in their character; that all people were not equal and that one needed to accept the world as it was and work for the best government given the constrains of surrounding realities. The American system of democracy was, however, wellsuited to us as a people. There was a question of republicanism constraining the excesses of democracy. For, as Gates said

Notwithstanding this goodly prospect-this golden sunshine, a dark and tempestuous cloud might then have been seen peering above the horizon, which was destined to exert its blighting influence on all that was grand-on all that was beautiful. "The fell-destroyer came;" the King was dethroned, and his family driven into exile. An unprejudiced observer might have predicted, from the spirit manifested on this occasion, the ultimate result of the French Revolution. But alas for humanity! It must ever stand, in the world's history, an illustrious example of the fact, that "goodly virtues" do, at times, "bloom upon the poisonous branches of ambition." The spirit of Liberty, as is always the case, where the great body of the people are not virtuous and intelligent, sunk into the most loathsome depths of anarchy and licentiousness. ${ }^{97}$

And while Gates celebrated the virtues of equality in the American system, he also had a fear for the future. For equality led to radicalism.

The spirit of revolution is abroad in the land; and in what it shall result can be known only to posterity. In our own country, we are rather apprehensive, that it will engender the lawless spirit of Agrarianism; already are its seed sown: that fanatical spirit, which has so plainly manifested itself in some parts of our country, both in religion and in politics, can forebode no possible good. It is but the smoke of a dreadful volcano, which lies concealed under the surface, and will ere long, unless the corrective is applied, and that speedily, break forth in all its ghastly splendor. ${ }^{98}$

Following on such gloomy addresses, the next year, 1842, proved to be one of the most important years before the war in the University history's for addresses in southern literature. In that year, the leading novelist of the antebellum south and a leading proslavery writer, William Gilmore Simms, addressed the University. dealt with the ways that society progresses. ${ }^{99}$ Why had Spain and France failed to conquer Florida? Why was it the English who ultimately

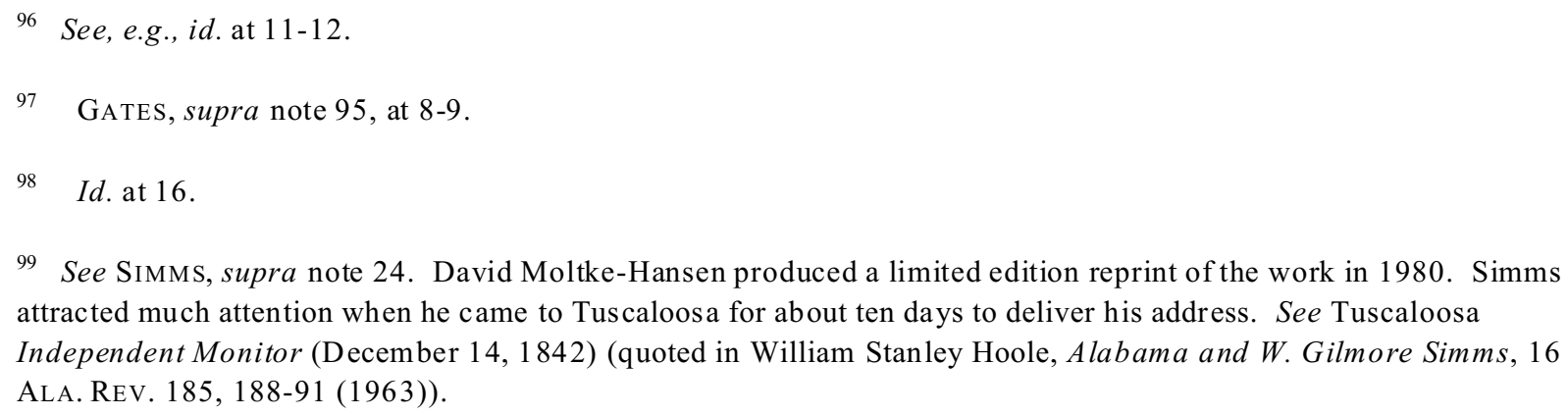
attracted much attention when he came to Tuscaloos a for about ten days to deliver his address. See Tuscaloosa Independent Monitor (December 14, 1842) (quoted in William Stanley Hoole, Alabama and W. Gilmore Simms, 16 AlA. Rev. 185, 188-91 (1963)). 
conquered Florida? Because, the English were able to turn it into a home, while Spain and France "sought either for gold, for slaves, or for conquest." 100 The American Revolution was the natural result of Americans' desire for independence and of the excesses of Great Britain. Yet, it also demonstrated Americans' patience and moderation, their reason and sense of natural justice:

Such a people are not prone to change-are slow to excess-slow to revolution-considerate of life-reserved, cautious--fond of acquisition-apt to be moral, proud, prudent and persevering. ... They are distinguished by the primary qualities of social permanence, method and consideration. ${ }^{101}$

For Simms, the United States, faced though it was with challenging economy, was progressing. It was the social principle that made progress conquered Native Americans and European nations. Simms' patriotic speech extolled the role of culture in its advancing beyond nature. Simms, like other southern thinkers, saw order through law and norms as the means for progress. "Society,--the presence and the restraints of neighbors, gentle, loving, and considerate,--the cheerful home-the certain school house-the 'decent Church that tops the neighboring hill'-those had saved them from this miserable descent." 102 Simms spent the concluding pages of his oration by dealing with the conflict between Americans' worship of money and society. It was a common theme for Simms, who so frequently lamented the failure to pay attention to intellect.

The following year, in December 1843, Caroline Hentz' poem, "Human and Divine Philosophy," was recited to the Erosophic Society for her by faculty member and librarian A.W. Richardson. She drew largely upon themes from Greece and Rome to illustrate the gradual awakening of humans to religion and then to Christianity:

The vision changes-myriad forms arise-

Light above light,-like gleams of sunset skies.

The great of later days-a swelling band,

Gathering in grandeur, from each distant land,

And mingling here, with out illustrious dead,

In solemn brotherhood, around us spread. ${ }^{103}$

Hentz saw the gradual progression of Christianity and natural and human science as naturally

\footnotetext{
100 Id. at 8 .

101 Id. at 14. See also id. at 17-18 ("Whatever may be the temptations of gold or conquest, be sure that no man fights so stubbornly, as he who, knowing the value of his home, fights upon its threshold; and he very humbleness of the British homestead in America, increased the indignation with which he strove against his foreign invader. . . It is not the value of the thing for which he combats. It is because that thing is his own; and it is partly to the veneration shown by British law to the British land-holder, that this lesson, teaching the profound value of the homestead to the meanest of Britain's sons, has served to make compact her social institutions, while the world around her was threatened with social overthrow.").

$102 \quad$ Id. at 37.

103 HentZ, supra note 21, at 11.
} 
occurring together. Humphrey Davy's invention of mining lamps made mining safer. ${ }^{104}$ Similarly,

Franklin, in the scathing path,

Red, with electric-breathing wrath,

Stood, while the thunder-spirits hurled,

Their arrows o'er a shrinking world,

And while they fell, a hissing shower,

Made them the vassals of his power.

Oh! with the lightning's pencil, trace

His name,--protector of our race,-

And let the thunder's deepest tone

Make his victorious honors known. ${ }^{105}$

Even greater than those, greater than Washington and Milton, was Christ. Hentz urged attention to him.

Be He within the midst!-The Haloed brow

Proclaims the Son of God-the same, who now

Breathes in our ears, the oracles of Heaven-

Truths, such as ne'er from Delphi's shrine were given.

The poem illuminates much of Hentz' world view-her interest in ancient Greece and Rome, her knowledge of the recent advances in science and the classics of literature, and the centrality of Christianity to her beliefs.

By looking to Hetzz' other work that we can expand our knowledge of Tuscaloosa culture. Caroline Hentz, who left an extensive body of work, allows us to peer inside the intellectual world of Tuscaloosa. Hentz taught at the Female Seminary in Tuscaloosa from 1843 to 1845. After her departure, though, that she published The Planter's Northern Bride, one of the most popular of the responses to Uncle Tom's Cabin. Hentz' proslavery fiction faced a steep uphill battle, because, like all fiction that defends the status quo, it is hampered by trying to make a sentimental story out of the imperfect present. Fiction is so well designed to critique, to point out problems; it is ill-suited, as Charles Sumner said on the floor of the United States Senate, to defend the present. ${ }^{106}$

This problem is illustrated by one of Hentz' more obscure short stories, "Wild Jack, or the Stolen Boy." It is about a young black boy, who is taken from his mother's custody by a horseman. The mother fears that he will be sold into slavery. Both the mother and the boy are

\footnotetext{
$104 \quad$ 'T is Davy, the modern Aladdin, whose hand Can, wand-like, the genii of science command,To bring forth their gems, and a palace to build, Whose summit, the sunbeams, unsetting shall gild. 
free; and she appeals for help to a college president, who organizes a search party for the boy. Then a white neighbor, the father of the horseman who took the boy, puts up money to buy the boy back.

The story is strange for many reasons, not the least because the setting is a kidnaping, which put a child on the road to slavery. Thus, buried in the sentimental story is an attempt to convert a free person into a slave. It required but little abstraction., for readers to realize that the horrors this family suffered (and that the white community mobilized to protect) were visited upon families in Africa (and occasionally in America). Hentz also designed the story to point out how Southerners frequently acted humanely. Thus, Southerners treated free blacks well. The implication is that if they would treat free blacks-people in whom they had no property interest-well, they would also treat slaves well. The story was laced with images of blacks and whites interacting amicably. ${ }^{107}$ Of course, the argument that sometimes slaves were treated well did little to counter the abolitionists' argument that in many cases they were not and that in any case slavery was dehumanizing.

There were other engaging, sentimental tales, which explore the goodness, as well as the greed, of the human soul. In "The Little Broom Boy," an affluent banker, Mr. Campbell, adopts an earnest young boy, Ellery Gray, who makes brooms. Mr. Campbell provides the child an education, "short of a college life." ${ }^{108}$ Later in life, after Campbell's daughter falls in love with Ellery, Campbell steals $\$ 10,000$ from the bank and allows Ellery to take the blame, including going to prison for a year. Nearing death, Campbell tells the truth, freeing Ellery. The story ends with Campbell taking the prison cell occupied by Ellery and Ellery living out a pious life. It is a story of pious hard work overcoming the doubts of the well-bred, a wonderfully middle class story and a warning about both inherited privilege and contempt for those from modest beginnings.

And then there is the haunting "The Black Mask." Young and beautiful Blanch falls in love with a man whose face was hidden by a black mask. She tried in vain to identify who he was; then a priest married the couple. Was the person behind the mask black as well? We will never know, because Blanche fainted as she removed his mask. And the story ends. The story is filled with images of white and black-the black mask and a black horse; white snow, pearls, and garments. The presence of the priest suggests the story took place in Louisiana, known for its mixed race couples.

"A Tale of the Land of Flowers" triangulated within the beauty of nature in the wilderness, where a military fort was established, and the passions of a young bride of the officer in command of the fort. The bride went riding, with another officer, outside of the fort and was ambushed and killed by natives. "She saw nothing of the wild Indians who infested the borders,

\footnotetext{
107 Caroline Hentz, The Banished Son and Other Stories of the Heart 47, 64 (Philadelphia, T.B. Peterson, 1856) ("There is no romance in the story of Jimmy, but there is truth, without any alloy of fiction. We have related it, as one of many instances of Southern kindness and humanity to a lowly race-whose feelings the Southron is too often accused of disregarding and trampling under foot."). See also Magnolia Leaves, in id. at 191 (story about a tree, which was cut down by a purchaser of property; metaphor for attack on heredity and then how hard work overcame that heredity); The Paradise of the Dead, in id. at 253 (importance of cemeteries).
}

108 Id. at $111,118$. 
and, grown fearless by unmolested tranquility, entreated her husband to let her roam in the woods for the wild flowers, which had given name to the luxurious region in which she now dwelt. This, however, he constantly refused, never allowing her to go beyond the limits of the fort, unprotected by his presence."109 The story thus juxtaposed love, betrayal, beautiful and destructive nature, and an outpost of civilization. Not much abstraction was needed to see how Southerners needed to struggle against a beckoning but dangerous nature and their own passions. "A Tale of the Land of Flowers" was the South in microcosm. It was also a morality tale about obedience. As Hentz concluded, "Let the young maiden who perchance may read this sad but true history tremble at the consequences of filial disobedience. God, sooner or later, avenges the violation of his sacred laws. She may not, like Leia, perish by the death-shot of the Indian, but she may be reserved for a fate more mournful still,-the slow wasting away of the heart, under the blighting influence of unkindness or perfidy." 110 Hentz is useful and unusual because she left such a rich literature, for many of the University's orators left little published work other than their addresses.

In the $1840 \mathrm{~s}$, the addresses continued to turn toward sectional and proslavery themes. Many of the addresses are concerned with the sectional divisions and the meaning of history. ${ }^{111}$ Others address the character that students should strive for-such as manliness, individuality, or knowledge. ${ }^{112}$ But even those that focus on knowledge differ from Tutwiler's careful work that calls for students to develop the virtue of thoughtfulness. For those later orations emphasize a steady determination to learn settled ways of thinking.

John Foster's 1843 address on the "Literary Spirit of the Present Day,"113 is a typical celebration of the role of learning, and scholars in American culture, which ends in celebrating hierarchy. Foster begins with an emphasis on the "Republic of Letters."114 Like Emerson's "American Scholar," Foster reminds that reform is afoot. "[T] he age calls aloud for action; our laws are to be improved, our institutions perfected, the public mind elevated, and the public taste

\footnotetext{
109 Id. at 183.

$110 \quad$ Id. at 187.

111 Benjamin F. Porter, the past and the Present. A Discourse Delivered Before the Erosophic Society of the University of Alabama (Tuscaloosa, M.D.J. Slade, 1845).

112 See Hayne, supra note 112; A. A. Lipscomb, the Morbid Exhibitions of the Human Mind. An Add Ress Delivered Before the Erosophic and Philomathic Societies of the University of Alabama on Their Annivers ARy OcCASion, December 19, 1845 (Tuscaloosa, M.D.J. Slade, 1846); Thomas Newton Wood, AN Address Delivered Before the Two Literary Societies of the University of Alabama, in the Rotunda, July 4Th, 1840 (Tuskaloosa, M.D.J. Slade, 1840). Lipscomb was born in 1816 and became a Methodist minister, then Chancellor of the University of Georgia from 1860 to 1876 and later a professor at Vanderbilt University. See 3 OWEN, supra note 39, at 1052.

113 John Foster, An Address Before the Philomathic Society of the University of Alabama, on the eleventh anniversary of the Society, December 12th, 18433 (Tuscaloosa, Journal \& Flag Office, 1843).
} 
refined." 115 He saw a particularly role, as did Emerson, for the scholar to engage. "The scholar should not be satisfied to dream away life in a closet." 116 Fosters departs from Emerson in the lessons he provides for scholars. They should not be wild Transcendentalists. They ought, instead, to be steady reformers. The French Revolution, while it reveals lessons about the power of the press, reveals also the dangers of change. There are other lessons in the danger of the rationalism of the French Revolution. He criticized Voltaire's writings and the French Revolution, ${ }^{117}$ even as he celebrated the printing press and the diffusion of knowledge ${ }^{118}$ and the role of law. ${ }^{119}$ Foster's clarion call for progress in social institutions notwithstanding, his was a moderate brand of reform.

Thus, even as Foster in 1843 and Hayne in 1840 spoke of typical themes of the virtue of intellectuals and of values other than making money, they also pursued an important southern theme: the role of the intellectual in stabilizing society. They were intellectuals and conservatives at the same time, even as Emerson was an intellectual and a radical. Those southern intellectuals who defended the status quo benefitted from having a well-established and well-financed world to defend. They benefitted from having that system to defend, even as the proslavery sentimental novelists faced an uphill struggle defending the same system. They were intellectuals using their minds to argue, in line with Alexander Pope, that what was, was right, or at least was close to right. Part of their defense of what was came from a belief that the world had evolved slowly and in ways that balanced competing considerations, so that the world-while imperfect-was the best possible one. That acceptance of the world as it is was a hallmark of conservatism, as Blackstone and Burke, among many others, has explained. The common sense moral philosophers popular in the south taught a similar lesson: that by scientific study of the surrounding world and "what is," one might arrive at proper understanding of and appreciation for the world. ${ }^{120}$ All we needed was a scientific study of the world.

Albert Forney's 1843 address to alumni, given two days before Foster's address to the literary societies, dealt with the typical subject of American literature's prospects. ${ }^{121}$ It was part

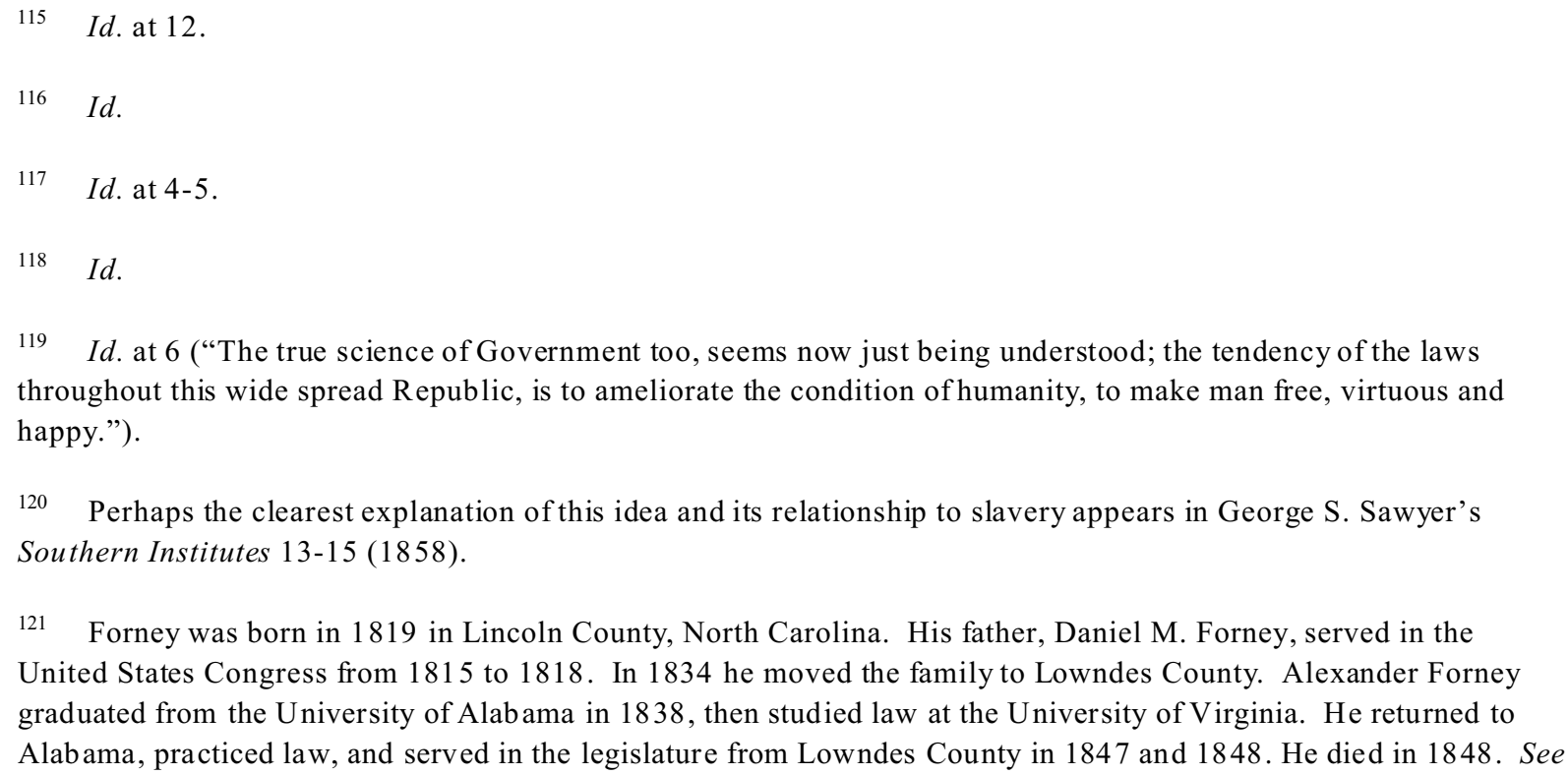


of defining American culture and the role of colleges in that culture. Forney presented both challenges to and opportunities for literature in America. The challenges included "the unsettled condition of our people"; "the absence of an international copy-right law"; "the small value we place upon literary attainments." 122 The opportunities included "recognition of perfect equality among all men," which would be reflected in the literature. ${ }^{123}$ Forney, like Meek and Gates, saw the connections between law, morality, and literature. "Our government, then, as its tendency is to improve society, is favorable to the growth of that which is equally the reflection of its manners, resources, and feelings. And in proportion as it becomes settled, and its laws are sanctioned by the moral force of the community, this mental activity is directed to the pursuit of literature." 124 This was another subtle connection between the literary addresses and legal thought, which illustrated a rich understanding of jurisprudence. This insight was central to judicial understanding and to legislative debate. Legislators often spoke about the ways that values as expressed in law would influence a people's character. Thus, in debate over the Fugitive Slave Act, members of Congress on both sides of the debate speculated on the implications of the law for national character. ${ }^{125}$

The institution of slavery was another of the factors favorable to the development of literature, in Forney's mind:

To high intellectual culture, a class of individuals, upon whom devolves the sowing the seed, and ingathering of the harvest is indispensable. "How can he get wisdom, that holdeth the plough, that glorieth in the goad, that driveth oxen, and is occupied in their labors, and whose talk is of bullocks." And whether beneficial or not, in every society, how free soever it may be, there must be a portion of its members, destined to perform its drudgery and labor, whose habits of life and dependence necessarily constitute them mercenary and selfish. . . . By a wise decree of Providence, a peculiar race of men are made to perform these menial services, a race that is as far below our association, and as incapable of corrupting it, as are the suffering serfs to corrupt that of the lordly Britton; and whose very enslavement has elevated them from ignorance and misery, to the blessings of religion and happiness. It becomes us, then, to cherish an institution, in the establishment of which we had nothing to do. ${ }^{126}$

Forney was certainly proslavery, but his discussion indicated at least a sensitivity to the criticisms of abolitionists; he spent some time attributing slavery to people other than the current generation

\footnotetext{
3 OWEN, supra note 39, at 595. Forney's two brothers, John and William, served in the CSA. John was educated at West Point; William graduate from the University of Alabama in 1844. 3 OwEN, supra note 39, at 596-97.

122 FORNEY, supra note 25 , at 7,8,9.

123 Id. at 11 ("And in proportion as it becomes settled, and its laws are sanctioned by the moral force of the community, this mental activity is directed to the pursuit of literature.").

$124 \quad$ Id. at 11.

125 See, e.g.,

126 Id. at 12 (quoting Ecclesiasties 38:24).
} 
of southerners and to Providence. In addition to slavery and the idea of universal white male equality, he found the newness of America as the final opportunity, for the American:

belongs to a government just commending its existence, entirely different from any the world has witnessed. Society is yet developing its resources and feelings;-its wants are yet to be satisfied, and its energies called out. The natural objects that surround him, and that must, in a great degree, modify his feelings and character, are not the worn themes of ages. The grand and magnificent mountain scenery of his country, its picturesque landscapes, and expansive plains, are yet to become famous in song and story. ${ }^{127}$

Forney's address illustrates the way that the United States would remake the world. That remaking, he predicted, was in morals and in literary culture. He believed there would be much advancement:

A new era must soon take place in the tastes and feelings of mankind; and much that is now written, must pass under a severe and rigorous review. Society is re-molding itself, even in the most celebrated states of the old world. New interests are elicited, and new principles are to be settled. Religion has thrown off the disguises and false pretensions that, for so long a time, made her a terror instead of a blessing to a people. The doctrine of the church as well as of the government being, "Honor all men." May we not hope, that this our country will become the theatre of this grand reformation, and that from here, as from the great centre, will go out influences to purify and to exalt the literature of the world. $^{128}$

Those concluding remarks are suggestive of what judges were doing, too. ${ }^{129}$ And he certainly thought that laws were closely related to larger culture. As he said, "Laws are but the embodyment of public opinion, and this public opinion is nothing more than a general expression of the tastes and feelings of the whole community, or of those who represent it, whether kings with their parliaments, or small societies of noblemen."130

Benjamin F. Porter's second address, given in 1845, nine years after his first, is much less explicitly political than his first. Where in 1836 he focused on the abolition of capital punishment, in 1845 he turned to a metaphysical topic: "The Past and the Present." The strange address links humans together in a chain of the past, present, and future. Where others criticized the decline of the present age. Like most of the University of Alabama orators, Porter saw more hope in it. While some might read ancient literature as mourning the loss of the old, Porter found a different message. Although a poet "at Marathon, narrates in plaintive verse the beauty of the institutions of Greece, and utters mournful judgments upon her oppressors," there is possibility

\footnotetext{
127 Id. at 13. Forney contrasts the vibrant, new American scenery with that of Europe. The constraints on the mind in Europe may suggest some of the constraints imposed upon European jurists: "The mind, thus walled around with objects as familiar as household words, sees but one beaten track ahead, and patiently sinks into the dull task of imitation." Id. And in the United States, by contrast, the mind of the poetry, orator, and novelist (and perhaps also the jurist) is freed from those constraints.

$128 \quad$ Id. at $15-16$.

129 See infra pages 55-61.

130 Id. at 10.
} 
for rebirth.

The germ of a new being reposes in every perishing husk. The nations, institutions, the men of one age, are but dead bodies to the souls of succeeding times. Death is the sleep from which another existence wakes up. Like the green ivy, which reaches its utmost height only through time-broken crevices, each era lives and advances upon the ruins of the last. The flame which burned so brilliantly on the alters of the Grecian, it is true, is extinguished there; but it enlightens land boasting a more rational and widely diffused liberty. ${ }^{131}$

Porter understood that humans existed in different states of civilization; and that some civilizations, having risen, declined. But he saw the overall tendency of humans toward progress. And he used an analogy to the earth's development to illustrate that general progression. He spoke with the precision of a geologist about the earth's evolution-the formation of the earth, the strata of rocks, the floods, the early giant plants and animals. ${ }^{132}$ From that brief study he then hypothesized that "Man bears the relation to the moral world that the primitive rocks, the foundations of the earth, bear to physical nature. ${ }^{133}$

Porter wanted to understand how the how world fit together-the "various characteristics of the religion, philosophy, laws, scientific improvements, and social manners of the human race."134 But he was skeptical of the reverence for history. "A simple truth of history, like a single ray of light separated in the phenomena of polarization, thus produces various colors calculated to amuse the fancy." 135 That fascination was misplaced, in Porter's mind, for "as a mass, men of this day as much exceed in mind and morals, those living two hundred years ago, as those living two hundred years hence, will exceed the present generation." 136

Porter surveyed the multiple ways in which the present excelled over the past: in religion, in philosophy, in law. In each of those areas, great progress had been made. The progress in religion came about, in his mind, through propagation of simple truths:

Unlike every other system, it has been established in peace; without force, and without money. No war, no human sacrifices, no political connections, lie at the base of its structure. Its promoters have been disinterested; its sentiments couched in the sublimest simplicity of language. It has interfered with the authority of no government; with no man's social duty: It has taught obedience to the law; embraced among its commands

\footnotetext{
131 PORTER, supra note 111 , at 6.

132 Id. at $8-17$.

133 Id. at 17 . He continues, "Both have been gradually developed; both have served, in their turn, the eternal purposes of truth and justice. In the one case, we have seen the rocks raised up amidst awful convulsions, only to crumble beneath external influences and fertilize the plain; we will now trace, in the other, the process of mental developments, as they have gradually, but certainly advanced towards perfection and usefulness." Id. at 17-18.

134 Id. at 18 .

$135 \quad I d$.

$136 \quad I d$. at 19.
} 
every regulation necessary in life; enforced benevolence; united the family circle; and even required the slave to obey his master. ${ }^{137}$

He told a lengthy story about the advancement of modern law over the arcane and arbitrary systems of ancient Greece and Rome and of the extraordinary technological advancements of the nineteenth century. Porter's discussion of the changes in law warrants extended treatment. For Porter depicted a legal history of Greece, France, and even of Great Britain filled with arbitrary pronouncements of judges, lack of respect for judges, and irrational rules of evidence:

The state of the laws of ancient times . . . like all human institutions, has varied; at one time challenging the admiration, at another, the abhorrence of men, frequently surrounded with a venerable mystery, into which the unprofessional eye has not dared to obtrude; often displaying unmeaning and useless forms eliciting only the contempt of men. ${ }^{138}$ His was an optimistic message. He looked forward to a new, more moral world; and he thought his listeners would see that world. In closing, he spoke of Socrates' noble death and the belief (with which he began the address) that death is accompanied by renewal:

Trace the progress of man's mind during the intervening eras, and conjecture what will be its state, when, fifty years hence, you stand on the Pisgah of another age, and view the glorious scene beyond; when pointing to another race, whom your talents and virtues have led onward in sight of new promised lands of knowledge, encompassed by a more refined atmosphere, and still nearer, and nearer yet, approximating to the sphere of the Deity;-Universal peace blessing its happy plains; Religion resting on calm faith and unclouded reason; Social life, a rational association of good men; Politics, Patriotism; the Arts, usefulness; and Literature, truth? ${ }^{139}$

Porter's optimism looked to progress in human thought. And he urged individuals to work hard and act morally to ensure that continued progress.

B.W. Huntington's ironically titled address, "Individuality," also given in December 1845 , was about the duty of the individual in society-the belief that each person has a role to fulfill, no matter how modest. Huntington emphasized the duties of those roles, such as truth and connections to society and God. "Please him where you may, you cannot isolate him from those currents which ever pass and repass along the electric chain that connects him with a higher sphere." 140 Huntington believed that each individual had an innate sense of duty and he urged them to fulfill those senses. "The Fathers of our Freedom, even now, in their starry mansions, piously covet your opportunities. It is your province to consummate what they began, and in

$137 \quad$ Id. at 19.

138 Id. at 24-25 (citing Jules Michelet, ORIGines DU DROIT FRANÇAis CHERChÉES DANS LES SYMBOLES ET FORMUlas DU DROIT UNIVERSEL (Paris, L. Hachette 1837)). Other works by Michelet were in the University of Alabama's library catalogue for 1848. See RichARDSON, supra note 22, at 153 (listing 1 J. Michelet's History of France (G.H. Smith trans. 1845) and J. Michelet, History of the Roman Republic (William Hazlitt, trans., Literary Miscellany, 1847)). Given the dates, Porter obviously could not have relied on either of those volumes in the University's library. His citation demonstrates that Michelet's works were in circulation.

139 PORTER, supra note 111 , at 38-39.

140

HunTINGTON, supra note 24, at 21. 
your success there will be found the greater glory." 141 The ultimate mission of the scholar is to join philosophy and Christianity so that "moral resplendency can shine forth," just as "by the combination of two inflammable gases you produce the dazzling Drummond-light."142 Huntington did not share the breadth of learning nor the vision of Porter.

The addresses increasingly reflect the shifting attitudes toward proslavery thought, as well as toward hierarchy and order. ${ }^{143}$ They also reflect a shift toward an understanding that the University is a place of education of very special people-men who were separated from the rest of the Alabama's society. Joseph Wright Taylor's 1847 address "A Plea for the University," is particularly illuminating. ${ }^{144}$ Taylor was born in 1820 in Burkesville, Kentucky and graduated from Cumberland College in 1838. He served in the Alabama legislature from 1845 to 1849 and also served as editor of the Eutaw Whig. Taylor was obviously keenly interested in education, for he served as trustee of Southern University. ${ }^{145}$ He offered a series of justifications for the University. He saw the University as training the intellectual leaders of the state. Those leaders would help spread learning throughout the state.

High seminaries of learning do more for a nation than to develop its gifted intellects; they elevate the great mass of its mind and give it new impulses and nobler aspirations.... Is one great mind developed and sent forth from the University? It becomes a sun in the intellectual firmament, illuminating the valleys as well as the mountain tops of society. Thousands of inferior minds rejoice in its brightness and are led by its guidance. . . In this way all who may not be able to visit the fountain source, may yet drink of its cooling waters percolating through channels which pour the refreshing tide through all the ramifications of the social edifice. ... This diffusible equality of knowledge constitutes the agrarian law of the kingdom of mind, by which its riches are distributed, in due proportion, among all the inheritors of reason. ${ }^{146}$

Taylor employed many analogies to the physical world in discussing the contributions of the University of Alabama to the public mind. For instance, he likened the University to "electric bars" that when "passed over metallic particles [students] attract them to their surface, when, in due time, they fall off to be succeeded by other particles, until the whole mass is brought under electric influence." The students then returned to their home communities and, like the particles

\footnotetext{
141 Id. at 18 .

$142 \quad$ Id. at 23.

143 In that regard, they track the trajectory of thought in antebellum universities. See Eugene Genovese, Higher Education in Defense of Slave Society, in Eugene Genovese, The Southern Front: History and Politics in the Cultural War 92-106(1995).

144 Joseph Taylor, A plea for the University of Alabama: An Address Delivered before the Erosophic and Philomathic Societies of the University of Alabama on their anniversary occasion, August 9,1847 (Tuskaloosa, M.D.J. Slade, 1847).
}

See 4 OWEN, supra note 39 , at 1651.

TAYLOR, supra note 144 , at 15. 
that fell off the electric bars, "help to electrify" the masses "by imparting portions of their own supply." 147 He saw the University as educating teachers for the common schools, which would then bring the University's light and morals, to the rest of the state. The University, moreover, prepares people for participation in the "well-regulated popular sovereignty." 148

Prime among the justifications for studying at the University was its support for slavery. For, as Taylor said, "The University is useful in enabling the State to protect the peculiar rights and institutions which belong to it, as one of the Plantation States of the South."149 Taylor professed love for the Union and hope that a destructive conflict would never occur. "Never may [the Union's] proud banner flutter out, with diminished stars and stripes, beneath skies blushing red with the hue of blood shed in the fratricidal conflicts of the warring fragments of a once united and powerful confederacy!"150 The institution of slavery was essential to Southern wealth, constitutionally protected, and morally right. Slaves "have grown up with us, and have become an element of our social life, which cannot be, harmlessly, removed. We believe them to be lawful, judged either by the laws of reason or by the canons of Revelation."151 But the South was under attack by those who held a "misguided philanthropy": "The pulpit and its instrumentalities, the press and its agencies, are the weapons they yield. The world is the field of battle; mankind the spectators; institutions, vital to the South, the guerdon of the victor; God and the right the arbiters of the final issue." 152

And it was Southern colleges and universities that would provide the defense: "the champions of the South must be her sons, their weapons the pulpit and the press, their schools of discipline our own Colleges and Universities." 153 Taylor would not rely on those from the North nor those trained in the North. "A hireling soldiery are as mercenary in a moral as in a physical contest. They may turn their weapons against their employers, and help the other party." This was simply a question of training people loyal to the South and equipping them with the right arguments:

The sons of the South are its legitimate, its reliable, and its appointed defenders; and, in the Universities of the South, must they be imbued with the skill and force in the use of the weapons of reason necessary to the high encounter to which they are called. If they be educated elsewhere, may they not imbibe the doctrines of our assailants, and thus, returning to us in the guise of friends, help to drag over the walls and into the very citadel of our domestic Troy, some fatal horse pregnant with the implements of fanatic

Id. at 20 . 
propagandists and unreformed reformers? ${ }^{154}$

Taylor used the example of a man from Kentucky, who was educated in New England, and returned to his home state as an abolitionist. (This is a reference to Cassius M. Clay, who was educated at Transylvania University and then later at Yale.) Clay was unsuccessful, but "as when Lucifer fell from the bright sphere of heaven, there is one less in the ranks of the champions of God and the right, and one fallen spirit more to tempt others to rebel violence and foul revolt against institutions and the rights of the South."155 Taylor was happy that Clay had been ineffectual, but he worried that others might come back from northern educations with similar abolition views. "Suppose one hundred or five hundred such erring minds were to turn loose their energies in the mad work of fanaticism in the State, how long would it be before Kentucky would see her blooming fields redden with blood shed in a servile war?" Here we see Taylor's principle of the educated spreading their influence working again (though obviously for ill in his mind). ${ }^{156}$ Should Alabamians send their children, Taylor asked rhetorically, "to be educated in the colleges of other States, that they may return with dangerous heresies coiled, like serpents, in their hearts, which will leap forth some day, instinct with a powerful vitality, to destroy the peace and to endanger the institutions of the State?"157 There were, of course, other advantages of the University. One important one was the opportunities it gave to poorer Alabamians. "The University," Taylor concluded, "is the great equalizer of ranks in our society, correcting the irregularity of fortune in the rich, by equality of mental cultivation in the poor."158 Taylor looked forward to the future when the University would be proud of its role in the cultivation of morals and education throughout the state.

After Taylor, there is a decrease in the frequency of publication of literary addresses. One alumni society address, on the state debt, was published in $1848 .{ }^{159}$ The next published address was John Pratt's speech to the alumni in 1850 on "Duties of Educated Men." Delivered on July 8, in the wake of the Fugitive Slave Act and John C. Calhoun's death, Pratt was focused on the practical and weighty issues of contemporary politics. Pratt had just joined the University of Alabama faculty. ${ }^{160}$ He dismissed "the pleasing illusions so often thrown around this occasion."

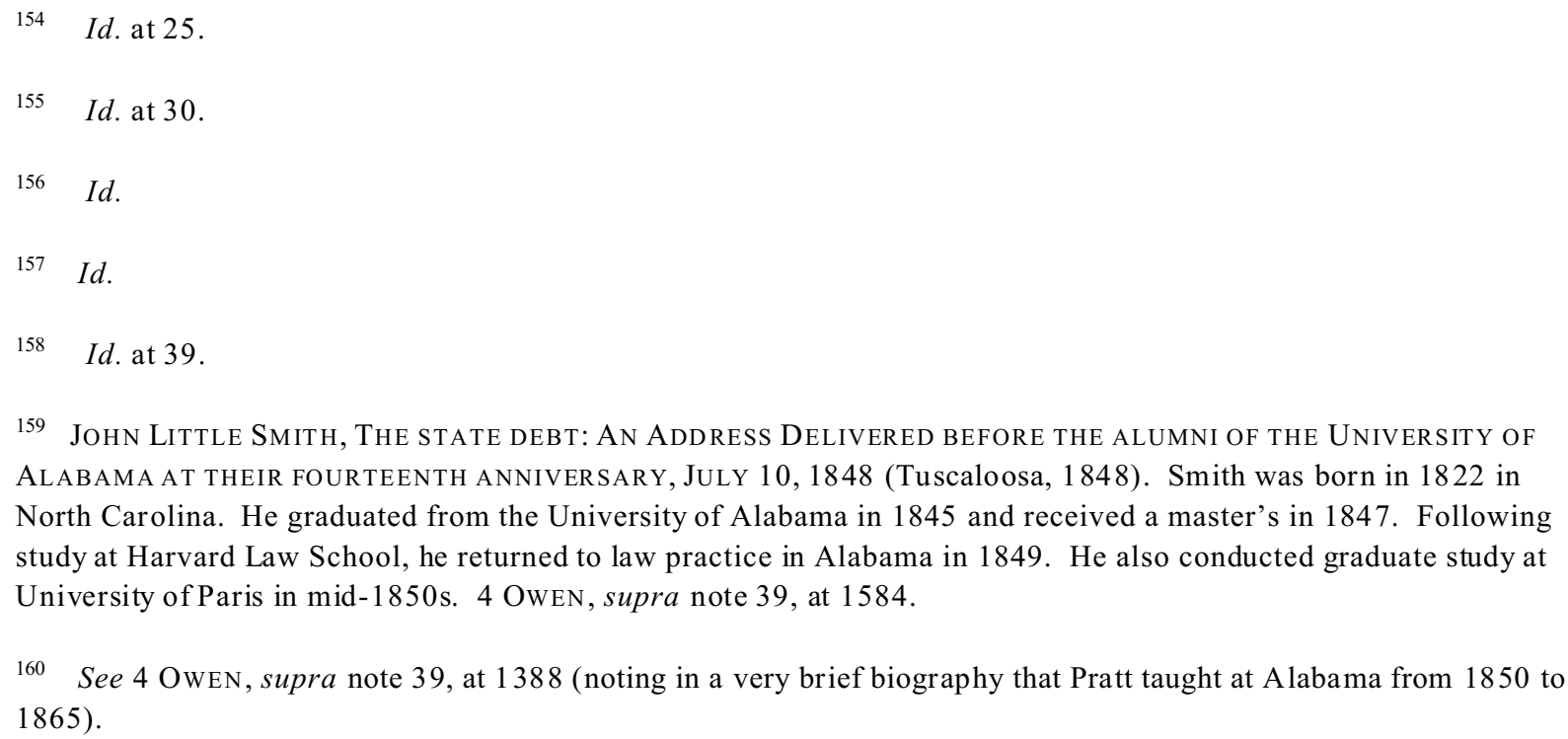


He did not imagine "that we are wandering amid the classic groves of antiquity." Instead, he sought to "remember that the realities, the practical concernments of life are here."161

Pratt was interested in defense of the "men of the mind." For he thought that "the sovereigns of a nation are its educated, thinking men." Those educated people-the same ones that Taylor had celebrated as the bringers of morals and education to the masses-were the leaders. What they believed and acted on would set the tone for everyone else. "The law of the descent of thought, from the higher orders of intellect to the lower, is as constant and unvarying, as the law of physical gravitation."162 There often was hostility to the "aristocracy of the mind," just as there was to wealth. Such, Pratt believed, was what those well-educated leaders of the community were up against. There was, moreover, a sentiment common among even the wealthy planters that there was no need to pursue an "extended intellectual culture," for knowledge had little utility. ${ }^{163}$ Pratt, like Taylor, hoped for further support of education by the educated.

Educated people were, moreover, the guardians of the nation's government, policy, and laws. He wondered whether "that which touches all our most intimate concernments, as owners of property, as the component parts of a great nation, be forever consigned to the keeping of ignorant and unprincipled men?"164 Pratt urged his educated audience to take action, for "every thing that is valuable to nations and individuals, is subject to the control of the civil authority." He worried about the struggle over ideas that was taking place and predicted a violent controversy. For there was an "important place assigned to abstract principles, abstract questions in morals, and sickly sentimentalities about the sacredness of the human person, in the political discussions of the day." 165 Those passions indicted that "a storm or violent struggle-perhaps revolution, is at hand." ${ }^{66}$ Legislators, judges, lawyers, all needed college education as

\footnotetext{
161 John Wood Pratt, An address delivered before the Society of the Alumni of the University of
} Alabama, July 8Th, 18503 (Tuskaloosa, M.D.J. Slade, 1850).

$162 I d$. at 4.

163 Id. at 11 (Planters argue "that Latin, Greek, and Mathematics cannot make cotton; that Logic, Metaphysics, and Chemistry cannot drive a gin; and therefore they conclude that the young planter has no business at college.").

$164 \quad I d$. at 19.

165 Id. at 20.

166 Id. (quoting without attribution Samuel Taylor Coleridge, the Statesman's Manual; or the Bible the Best Guide to Political Skill and Foresight: A Lay Sermon, Addressed to the Higher Classes of Society. .. 18 (London, Gale \& Fenner, J. M. Richardson, and J. Hatchard, 1816)):

It is with nations as with individuals. In tranquil moods and peaceable times we are quite practical; facts only, and cool common sense, are then in fashion. But let the winds of passion swell, and straightway men begin to generalize, to connect by remotest analogies, to express the most universal positions of reason in the most glowing figures of fancy; in short, to feel particular truths and mere facts as poor, cold, narrow, and incommensurate with their feelings.

The invocation of Coleridge suggests Pratt's world view: that of the centrality of ideas, rather than economics, to politicians. And it reminds us again of the sophisticated ideas, the subtle understanding of human motivations, circulating in Tuscaloosa. Coleridge's concern for the role of religion in setting those ideas appears later in Pratt's address when he remarks on the recent seventy-fourth anniversary of American Independence. It is "the most 
statesmen. ${ }^{167}$ He concluded with a call to scholars to take action: "we must translate words into deeds, and thought into action."168 In little more than a decade, much of what Pratt predicted occurred. And there would indeed be action, led by the well-educated statesmen of Alabama. ${ }^{169}$ George Shortridge also delivered an address to alumni in 1850. Shortridge was born in 1814 in Mt. Sterling, Kentucky and graduated from the University of Alabama in 1833. He became a lawyer in 1835. He ran for governor on the Know-Nothing ticket. ${ }^{170}$ Like Professor Pratt's, his address focused on education. Like Taylor, he was educationally zenophobic. "The formation of a distinct, independent State character, is absolutely conditioned upon the education of our youth upon their native soil, in our own social atmosphere, amidst our own political institutions, under our own southern sky." ${ }^{171}$ Shortridge justified and celebrated the role of the University's education for southerners:

Our social institutions, our social and political sympathies are intensely southern. . . Are you doing this, when you send your sons to New England, to Virginia and to the Carolinas, to have their sympathies and opinions molded under influences, which may prepare them for other circumstances, but not for ours-influences moral, social, and political, which now threaten the Union and jeopardize the rights of the South? ${ }^{172}$

After 1850, there was only one other literary addresses delivered under President Manly's watch that saw publication in pamphlet form. That was an address given to the Alabama chapter of Phi Beta Kappa in 1854 by Professor Frederick A.P. Barnard, "Art Culture: Its Relation to National Refinement and National Morality." That lecture, which emphasizes the role that art plays in culture, presumably was not selected by President Manly, because there was a dispute at the time between Barnard and Manly over control of Phi Beta Kappa. Barnard surveyed art in differing cultures, such as ancient Egypt and Greece, and modern Europe, to suggest an "intimate connection between" people's "intellectual attainments, their social refinement, and their

\footnotetext{
convincing demonstration of an inherent vitality somewhere in American Republicanism; but it is more;-it is an illustrious example of that higher truth, which as a nation, we are too prone to disallow;--that, GOD IS IN HISTORY; THE GOD OF ABRAHAM, OF ISAAC, AND OF JACOB." Id. at 22-23.

167 See, e.g., PRATT, supra note 161, at 25, 28 (referring to "the Bible as the 'Statesman's Manual'”).

$168 I d$. at 29.

169 See, e.g,., William BARney, The Secessionist Impulse (2 ${ }^{\text {nd }}$ ed. 2005) (discussing Alabama's move towards secession).

1704 OWEN, supra note 39, at 1555.

171 George D. Shortridge, An address from the alumni of the University of Alabama, to the People of Alabama 7 [1850] (typescript copy in Hoole Library, University of Alabama).

172

Id. at 8 .
} 
aesthetic cultivation."173 From that he urged greater attention to the cultivation of fine art, which would help raise us above the level of utilitarians. "We need," he concluded, "a national taste more highly cultivated." $" 174$

With Taylor's address, the University reached the zenith of expressions of fear of the North and the culture of zenophobia. The nature of the literary addresses continued to change, moving in many instances toward proslavery thought.

\section{Presidency of Landon Cabel Garland, 1855-1865}

If the fruits of intellectual culture have not been so profuse among us, have we not been more fortunate in the development of the whole man, and may not the horseback exercise and the habitual use of the deadliest weapon of modern warfare, to which we are trained from our youth, be fairly set off against some of that curious learning which exhausts itself in the effort to overturn the Ark of our fathers, and to commit the hopes of mankind to the phantom ship of an infidel philosophy? ${ }^{175}$

Edward Courtney Bullock, True and False Civilization (1858)

When Basil Manly left the University in 1855 to return to South Carolina, the institution was well-established, with a large faculty, a good physical facility, and a long tradition of literary addresses. Eight addresses from the period of Manly's successor, Landon Cabel Garland, have survived. ${ }^{176}$ Two are important for the purposes of this essay, because the speakers--Edward Courtney Bullock and United States Supreme Court Justice John Archibald Campbell-consciously engaged in speculation on the relationship of society to culture and the idea of progress. ${ }^{177}$ The six others are concerned with the role of the educated in Alabama society. ${ }^{178}$

\footnotetext{
173 ; F. A. P. BARNARd, ART CUlture, its RELATION TO NATIONAL REFINEMENT AND NATIONAL MORALITY AN oration pronounced before the Alabama Alpha of the society, of the Phi Beta Kappa, at its AnNiversary, July $11 \mathrm{Th}, 1854$ (Tuscaloosa [Ala.], M.D.J. Slade, 1854), reprinted in Representative Phi Beta KAPPA ORATIONS 115 (Second Series, Clark S. Northup ed. 1927).
}

174 Id. at 137. See also id. ("How few that build even expensively do more than heap up piles of brick and stone intolerable to the eye of cultivated taste! How many even of our public buildings, those monuments of folly appertain to our own University included, are open to the same objection.”).

175 Bullock, supra note 23, at 29.

176 Garland served as chancellor at Vanderbilt University after the Civil War. See Vanderbilt history; Garland biography.

177 R.B. Mcmullen, Truth, the Foundation of Genuine Liberty: An Address Delivered Before the Alumni of the University of Alabama, July 13, 1858 (Tuskaloosa, Ala., Independent Monitor Office, 1858); John Archibald Campbell, the Institutions, Duties and Relations of Alabama. An Oration Before the Erosophic and Philomathic Societies of the University of Alabama. July 12th, 1859 (Tuscaloosa, Jno. F. Warren, 1859).

178 C. C. Clay, the Love of Truth for its Own Sake: an Address Before the Erosophic and Philom athic Societies of the University of Alabama, at its Commencement in July, 1855 (Tuscaloosa, M.D.J. Slade, 1855); W. W. Lord, The wants of the South: A poem pronounced before the Phi Beta Kappa society of the University of Alabama, July 12, 1859 (publication data); William Russell Smith, The Uses of Solitude 
Bullock offered a particularly detailed world of hierarchy and opposition to radicalism. It is a classic southern work, which presents a rich picture of society from a southern, slaveholding perspective. It is a poignant contrast with Henry Tutwiler's oration. Born in 1822 in Charleston, South Carolina, he was educated at Harvard College, where he graduated in 1842. Bullock came to Eufaula and read law; he was admitted to the bar in 1846 and then practiced and edited a weekly newspaper, the Spirit of the South. He served in the state senate from 1857 to 1861 and during the secession crisis was Alabama's delegate to Florida. Thus, he was at the center of the secession movement and a prime advocate of secession. He enlisted in the Confederate Army and was promoted to colonel. He died of typhoid fever at the end of $1861 .{ }^{179}$

Bullock asked whether civilizations had an inevitable life, like that of humans, which must end in death. "Is the embrace of civilization sooner or later necessarily fatal, and is this the banquet of death to which it mockingly invites us?"180 History seemed to answer yes, for there were legions of examples-the Assyrians fell to the Persians, who fell to the Macedonians. Greece fell to Rome, which fell to barbarians. "The culminating point of what we call civilization in each, was but the beginning of a fatal decline; and the noon-tide splendor upon which we love to gaze, was but too surely ushering in the night of desolation that was to succeed." "181 But Bullock drew a distinction between true and false civilizations. The demise of civilization was not inevitable, but there were certain principles that had to be followed. "Courage, fortitude, independence, physical strength,-all the sterner qualities, flourish in man's primitive state, and the cultivation of a more advanced period seems to be a certain extent less favorable to their existence; but true civilization instead of destroying these high attributes, uniting them with the gentler virtues, will soften them by humanity, and dignify them by knowledge."182 True civilizations have hierarchy, which put people in their places. ${ }^{183}$ False civilization is flashy and concerned not with simple, manly princples, but with an excess of intellectual accomplishment. Bullock's world is one of false civilization, where there is

(Alabama Alpha of the Phi Beta Kappa Society of the University of Tuskaloosa, 1860); Boykin

The alumni orations were delivered by the leaders of the early Erosophic Society. See R. B. MCMULLEN, Truth, the Foundation of Genuine Liberty: an Address Delivered Before the Alumni of the University of Alabama, July 13, 1858 (Tuskaloosa, Ala., Independent Monitor Office, 1858); Shortridge, supra note ?. M.L. Stausel, "The University and the Higher Learning," University Pamphlets, Alumni Association Addresses, 50 086, folder 35, Hoole Library, University of Alabama. The address is discussed in Independent Monitor, July 16, 1857.

1793 OWEN, supra note 39, at 254-55.

180 Bullock, supra note 23, at 6,

181 Id. at 5.

$182 \quad I d$. at 7.

183 See also Edward C. Bullock, A plea for home education in the South: An address Delivered at the first annual East Alabama Female college, Tuskegee, July 14, 1852 (Eufaula, J. Black, 1852); Edward C Bullock, A eulog y on the life and character of John C. Calhoun, delivered before the Citizens of Eufaula, Alabama (Eufaula [Ala.] Jno. Black, 1850). 
insufficient virility.

English society during the middle ages, a period of feudalism and chivalry, was a true civilization. For society was rural, it developed virtues in men and women and workers were able to support themselves. ${ }^{184}$ (One is tempted to ask of Bullock, why did English medieval society not last.) With commerce-by which we might read capitalism-came the problem of modern civilization, vast differences in wealth. ${ }^{185}$ The Northern states displayed many of those problems. Capitalism lead to the reduction of white workers to the status of slaves.

It may be that they who sow the wind will one day reap the whirlwind, and will learn how easy is the transition from the principles upon which they have inaugurated a crusade against an institution older than civilized society, and a right of property as sacred as any that ever received the sanction of law, human and divine, to the bold avowal of the great French socialist, that "all property is robbery." 186

Bullock's framework explained the problems of New England. The dense population in New England led to the decline from the era of Revolution to Bullock's day. "Books have multiplied, education has penetrated every household, wealth has accumulated, learning is idolized, and yet are we not met on every side by the evidences of impaired manhood and decayed virtue?" 187 The signs of decline were everywhere in New England and those signs were that once solid New Englanders had become fanatic reformers, who disobeyed the law in a misguided sentimental concern for slaves:

Her great statesmen driven into retirement to make way for pedants and philanthropists by trade! The old cradle of liberty closed against her brightest intellect, because he dared to uphold the inviolability of a solemn compact against the assaults of the higher law; and Faneuil Hall, that once reverberated with the eloquences of Otis and of Samuel Adams, sunk into the echo of the insane drivelings of Exeter. The ermine of justice stripped from the shoulders of a judicial officer, the only charge alleged against whom, was, that he had sinned against the commonwealth by keeping his oath of office instead of obeying the mandates of an infuriated mob! . . . Scholarly essays, and conventions with any amount of choice rhetoric, to prove the intolerable tyranny of the moral law, and the imperative necessity for overturning society, church, and State, and practically reducing man to a level with the brute! ${ }^{188}$

By contrast with the North, the rural South is "true civilization." Of course, slavery was central to that civilization and economic progress. All "the statistics of life and health and

\footnotetext{
184 Bullock, supra note 23, at 10-11.

185 Id. at $14-15$.

186 Bullock, supra note 23, at 20. One might be tempted to speak of the progression from Locke to Kelo.

187 Id. at 20.

188 Id. at 20-21. Bullock attacked the Transcendentalists. Id. at 21-22 ("If, on the mysterious wires that connect us with that spirit world with which they profess to have daily communication, could be borne just one brief message from those sturdy old Puritans ... how would its withering condemnation blight the mystical, skpetical, transcendental and dyspeptical generation that disgrace their ancestry!").
} 
happiness proclaim in tone only less authoritative and commanding than the voice of God itself' that slavery for blacks is better than freedom. ${ }^{189}$ Bullock's address was not written as political theory, but as a proslavery jeremiad.

United States Supreme Court Justice John Campbell delivered an address, "The Institutions, Duties, and Relations of Alabama," the year after Bullock's, in 1859. ${ }^{190}$ Campbell discussed the moral and political philosophy reflected in the Constitution. He surveyed centuries of history leading to the Constitution and found in that history "a statement of the causes and conditions which have aroused and invigorated the human conscience and intellect for five centuries." "191 The history of the Reformation demonstrated, to Campbell's reading, that "there exists an order of truths which are immutable, not subject to the control of government or society, but to which the State in its corporate capacity, as well as its members, owe obedience." The problem became, how could a state preserve those truths (of which personal liberty was a critical part)? Here Campbell turned the lessons of history into a defense of the present. He praised England for its steady traditions. "There is among [the English] none of that presumption and pride that is displayed in rejecting the lessons of experience, the counsels and acts of ancestors, and they steadily refused to divide the life of their country by abandoning their old and seeking at large for new laws, institutions, and habits." "192 It was the revolution of 1688 that established the principles that Campbell most supported: "that political power exists of right in the entire society, and that government derives its sanction from the consent of the governed."193 Those principles appeared in the American Revolution, which was a sober return to original

\section{Id. at 23.}

190 See CAmpBell, supra note 177. Campbell's other extra-judicial writings include J.A.C., The Rights of Slave States, 3 Southern Q. Rev. 101-45 (1851); Slavery Among the Romans, 14 S. Q. ReV. 391-432 (Oct. 1848); Slavery in the United States, 12 S.Q.Rev. 91 (July 1847); John A. CAMPBELl, AdDress Delivered BEFORE THE Alum in Society of the University of Georgia ... A the annual commencement, in August, 1853 ; John A. CAmpbell, An address upon the life and public Services of John C. CAlhoun, delivered at Mobile, on the 13 TH OF DECEMBER, $1850 \ldots(1851)$.

One might find is surprising that Campell's Southern Quarterly Review article concludes with a quotation from Emerson's "Self-Reliance" and then a comment on it:

We quote this from no design of adopting the sentiment it contains; but simply to invoke the confidence and self-reliance that it implies. It is the cardinal principle in our institutions, that the people are competent to form and re-form their constitutions. New conditions have been created in our affairs-conditions never contemplated by the authors of the constitution. These conditions menace our peace and safety. The highest obligations devolve upon us to secure these from all peril. This can be done by a united and concentrated movement of the States most interested.

The Rights of Slaves States, supra at 145. See also Robert SAunders, John Archibald Campbell, Southern Moderate, 1811-1889 (1997).

191 CAMPBELL, supra note 177 , at 5.

$192 \quad$ Id. at 14.

$193 \quad$ Id. at 15. 
principles, rather than a radical break from England, and in the subsequent Constitution. ${ }^{194}$

The Constitution and the Northwest Ordinance, followed by local acts like the Alabama Constitution of 1819 established the principles of a government based in Christianity; subjection of the individual to the good of the whole; education and such other values as:

Enlarged commerce, intelligent industry, facilities of communication, wealth to promote the progress of science and liberal arts and to relieve indigence and penury, liberal and just legislation and efficient and vigorous execution of the laws, under the influence of a wise and regulated opinion of a religious, moral, and educated people. . . ${ }^{195}$

In such a well-educated and well-regulated society, legislation would be benign. Campbell's legal theory was that in a well-functioning society, legislation merely confirm and gently pushes morality in the right direction. Thus, legislation springs from and must be in line with the prevailing sentiments of the community:

Authority is then scarcely felt, so naturally and spontaneously do the members of society perform their appropriate functions; and when employed, it is to bring the members of society into closer union, by the gentle stimulants of law, literature, industry, and intercourse. Legislation then only consecrates as law, the duties that have their sanction in the public conscience; obedience is the grateful homage of loyalty, to right as declared by legitimate authority; and justice, as pronounced by citizens selected temporarily to distribute it without aid from the insignia or array of power, is executed through the reverent sentiment for the sovereignty and majesty of law, in a self governed, virtuous community. ${ }^{196}$

And in order to preserve the state, there must be "old customs, familiar household sympathies, the habits of subordination and obedience, the community of thought and opinion, the centres of worship" that hold the country together. ${ }^{197}$ Campbell supported the Union because he thought that it supported those connections. He found in the Constitution a further support for Union. The lecture allows us to the see how a Supreme Court Justice saw the meta-functions of law in supporting and working in conjunction with the community's sentiments and for the support of order against change. ${ }^{198}$ He ended the address with a quotation from Wordsworth:

So will God protect us, if we be

Virtuous and wise. ...

... by the soul

\footnotetext{
$194 I d$. at 16 ("The revolution by which colonies were converted into independent States, was the calm, grave, deliberate act of men who acknowledged all their responsibility and who knew that the facts would justify them before a candid world.").

$195 \quad I d$. at 22.

196 Id. at 22-23.

197 Id. at 25-26.

198

Id. at 32-34.
} 
Only, nations shall be great and free. ${ }^{199}$

The last antebellum literary address from the University of Alabama that was published before the war was William Russell Smith's Uses of Solitude, a poem delivered to the Phi Beta Kappa Society. Smith was born in Russellville, Kentucky, in 1815, and had studied at the University of Alabama in the early 1830 s, but did not graduate. He became a lawyer in 1835 , worked in Mobile and then Tuscaloosa as a lawyer and as editor of the Tuscaloosa Monitor. He served in Congress in 1860 and was a delegate to the 1861 secession convention and was briefly president of the University after the war. ${ }^{200}$ Like Barnard's "Art Culture" and W.W. Lord's poem. Smith's address was different from the other addresses; it was aimed at a more explicitly introverted, intellectual topic-the scholar's penchant for solitude and its benefits, the virtues of a quiet, introspective life of the mind. There were many uses of solitude, though. Toward the end, Smith suggests the power of solitude for even some practical purposes:

I sing the Solitude of Mind; the power

To draw the sense from its accustomed use

Of natural avenues; the power to be

Still in the uproar, deaf to all the shouts

Of angered multitudes; the power divine

To pluck form turbulence the time to think;

To shape the howling thoughts to themes divine,

And meditate perfections infinite,

While Fury races and moves tumultuous reign. ${ }^{201}$

With that, the antebellum period drew to a close. Many of the men who had trained at Alabama took leading roles in the secession movement and then later in the war. They put their ideas into action. It remains for us to make sense of the ideas in the literary addresses and to connect them to the world.

\section{Connecting Literary Addresses to the World Outside the Campus}

"The mind of a people imprints itself in its speech, as the light in a picture of Daguerre." Frederick Henry Hedge ${ }^{202}$

"Language is the organ of thought."

$$
\text { Joseph Henry Ingersoll }{ }^{203}
$$

\footnotetext{
199 William Wordsworth, September, 1802. Campbell's history is reminiscent of later-twentieth century interpretations. See generally Gordon S. Wood, The Radicalism of the American Revolution (1992).

2004 Owen, supra note 39, at 1594; Benjamin Buford Williams, A Literary History of Alabama: The Nineteenth Century 28-39 (1979).

201 SMith, supra note 178 , at 33.

202 Frederick Henry Hedge, Conservatism and Reform, in Martin Luther And Other Essays 129, 141 (1888).

203 Joseph Ingersoll Annual Discourse Before the Philomathean Society of the University of Pennsy lvania 9 (Carey, Lea, and Carey, Philadelphia 1827).
} 
Recent writing on intellectuals in the Old South has dwelt on problems that they faced. They were isolated, frequently ignored, limited in power. In brief, unimportant. Because of their small market and their small numbers, it was difficult to produce significant work. ${ }^{204}$ According to historian Drew Faust, they felt isolated, and a group of five of the most important (William Gilmore Simms, Edmund Ruffin, George Frederick Holmes, Nathan Beverly Tucker, and James Henry Hammond) thought of themselves members of a small "sacred circle." 205 Those intellectuals focused on the idea of moral stewardship: of a group of intellectuals leading the rest of the South. They sought to make themselves relevant by employing proslavery arguments.

Michael O'Brien's more recent assessments draw a somewhat more engaging picture. In the introduction to his 1982 anthology of literary essays, All Clever Men Who Make Their Way: Critical Discourse in the Old South, O'Brien made out a tentative case for a wider appreciation of the quality of the work of antebellum southern intellectuals, even if not so much their influence. "We stand in our understanding of antebellum southern thought where the study of the New England mind stood when Perry Miller came to revise the orthodoxy of Brooks Adams." "206 In 2004, O'Brien offered a magisterial defense of the southern intellectual with his 1200 page Conjectures of Order. ${ }^{207}$ So we might now say that we stand where we stood following Perry Miller's two volumes on the New England Mind. Going beyond his tentative 1982 introduction (but also perhaps cutting back somewhat from his claim that southerners paralleled northern intellectuals). He demonstrates that there was deep and rich thought across a spectrum of religious, historical, economic, and political thought, as well as significant productions in fictional literature. Surprisingly, legal thought (other than political economic thought) receives almost no attention. Perhaps O'Brien though that topic received sufficient attention in his other work, such as his biography of Hugh Legaré ${ }^{208}$ or that his treatment in Conjectures of Order of political economic works by people like Nathan Beverly Tucker met the needs. If, however, one seeks to trace ways that books shaped ideas, looking at law books and judges allows precision we rarely see in other fields. Moreover, southern judges produced an immense amount of thoughtful scholarship in the form of judicial opinions, which easily

\footnotetext{
204 John McCardell, The Idea of Southern Nation alism (1982).

205 Drew Faust, writing about the intellectual in the Old South in 1979, identified problems for them, including that they were not respected parts of society, that their limited resources and small numbers made it difficult for them to sustain a community. See Drew Faust, A Sacred Circle: The Dilemma of the Intellectual in the Old South (1979).

206 Michael O’Brien, All Clever Men Who Make Their Way: Critical Discourse in the Old South 2 (1982).

207 See O'BRIEN, supra note 20.

208

See O'BRIEN, supra note 4.
} 
compares favorably to that of their northern colleagues. ${ }^{209}$ O'Brien is more concerned with describing the intellectual world of the antebellum southerner and less concerned with describing their relationship to a world of action. Eugene Genovese is optimistic about the quality of southern intellectuals and believes that they were forward-looking people. The addresses can help us test those hypotheses.

\section{A. Mapping the Mind}

The Alabama literary addresses accomplish several purposes. By providing a set of data across nearly forty years, they allow us to pick out certain highlights. Perhaps most notable is the transition from late-Enlightenment thought to a world of hierarchy. The addresses also expand the scope of people we might think of intellectuals in the Old South; that is, they are offered from a wide variety of speakers, many of whom no one has ever cited as a figure in southern intellectual history, such as Henry Tutwiler, John Pratt, and Edward Bullock. And even for those whom we do sometimes speak about as intellectual like William Gilmore Simms and John Campbell, we see them in additional perspective because of their addresses. The lectures also expand our understanding of the scope of ideas in circulation and demonstrate the vibrant, diverse ideas held by antebellum Alabamians. We see a world of late-Enlightenment optimism for the cause of education. We see the idea of progress for the entire society through education, of stability through education, as confirmed by law. We see, particularly after 1840, a welldeveloped idea that the well-educated are the appropriate leaders of society and that hierarchy in society is proper and necessary. History from ancient times through the American and French Revolutions teaches that reform must be gradual. The political philosophy of Edmund Burke and William Coleridge held sway; the ideas of Christian morality, American republicanism, and a social order stabilized through law and education are their visions. It is a rich and welldeveloped world.

The addresses suggest, somewhat in contrast to Faust's view, that the intellectual circles may have been greater than previously believed; that more people may have cared about issues of the mind that we previously believed. The addresses also suggest that the proslavery argument was employed for wider purposes than Faust suggests. Thus, it is not so much a part of bending the subjects of study to make intellectuals relevant to society, as many smart and well-educated people employing the arguments because the arguments were relevant to them. The addresses suggest that the arrows of influence may have pointed from society and social needs to intellectuals, rather than the other way around. In contrast to some Northern intellectuals, who went against the grain of society, the intellectual in the South (particularly after 1840) went in the same direction. There was a linking of the interests of the wealthy, the powerful, and the intellectual. The picture that emerges contains elements familiar to several generations of historians: Eugene Genovese's picture of progress, though it is change from a world of chaos towards one of order and hierarchy. ${ }^{210}$ That progress toward order and hierarchy contains

\footnotetext{
209 Even a highly selective list of southern judges, such as Spence Roane, George Wythe, John Marshall, Thomas Ruffin, John A. Catron, George Lumpkin, Peter V. Daniels, John A. Campbell, suggests the favorable comparisons that are possible.

210 See Eugene Genovese, The Slaveholders' Dilemma: Freedom and Progress in Southern Conservative Thought, 1820-1860 esp. 4-8 (1993).
} 
important elements of liberalism (like respect for private property), as Louis Hartz wrote about. ${ }^{211}$ At many times, individuals' rights are subordinate to the community's need for order. Thus there is also talk of the republicanism so familiar to historians from George Frederickson to Lacy K. Ford to William Freehling. ${ }^{212}$ We may, thus, be moving toward a more comprehensive picture of the southern minds, which incorporates many elements and looks like that complex picture of Michael O'Brien's Conjectures of Order. For purposes of understanding the relation of political philosophy to action, perhaps Minashi Sinha's Counter-Revolution of Slavery has come closest to capturing the complex ideas of property, order, and dedication to preservation of that order and freedom for white men that propelled the south into Civil War. ${ }^{213}$ The addresses at Alabama, particularly in the years after the arrival of President Manly in 1837, offer an oratorical window into the ideas of the South's intellectual and political leaders.

Overall, the addresses also provide insight into the role of the University in intellectual life, for they provide a particular vantage on the role of the University in southern life and the place of the speaker in creating a southern intellectual culture. They celebrated the role that education might serve in leading to progress. ${ }^{214}$ One must, of course, be mindful of trying to push the analysis too far. For the addresses are aimed at the University audience and emphasize the importance of education. They try to provide balance to the utilitarian sentiments of the age. Some are anti-intellectual and overtly pragmatic. Some may offered statements so general as to be meaningless. The author of a short story about a Whig politician's first campaign characterized lectures that way: "The multitude frequently shouted applause in reply to some of his senseless declamation. I discovered that he dwelt with particular emphasis on the words, Liberty-Freedom-your County's rights, \&c. These are words calculated to make an orator appear to advantage; but, for my life, I could not discover why and wherefore he made use of them." 215

And yet, there was the belief by many that politicians spoke the language of moral

211 Louis Hartz, The Liberal Tradition in America (1955)

212 George M. Frederickson, The Black Image in the White Mind: The Debate on Afro-American Character and Destiny, 1817-1914 (1971); LaCy K. Ford, Origins of Southern Radicalism The South Carolina Upcountry, 1800-1860 (1989); William W. Freehling, The Road to Disunion: SeCESSIONIS TS A T BAy, 1776-1854 (1990); James Oakes, From Republicanism to Liberalism: Ideological Change and the Crisis of the Old South, 37 AM. Q. 551-571 (1985).

213 See Manisha Sinha, The Counter-Revolution of Slavery: Politics and Ideology in Antebellum South CARolina (2000).

214 See, e.g., John Patrick Daly, When Slavery Was Called Freedom: Evangelicalism, Proslavery, and the Causes of the Civil War (2002); David Ericson, Debate Over Slavery (2000) (discussing Hartz's vision of liberalism); Bertram Wyatt Brown, Hearts of Darkness: Wellsprings of a Southern Literary TRAdition 67 (2003) (citing Cash \& O'Brien). One might also add William R. Taylor's Cavalier and Yankee, with its emphasis on proslavery and abolitionist literature.

215 The Whig-Or the Diary of a Young Candidate, 2 BAChelor's Button 11 (1838). The Bachelor's Button was a literary journal published for a short time in Tuscaloosa and then Mobile, which was edited by William Russell Smith. 
philosophy and continued to engage the ideas they had first met in college. One character, old Senator Burton, in William Russell Smith's novel As It Is, was said to be a follower of literature and frequently alluded to it in debate:

He was familiar with all literature. In his youth he had been a student; and in his busy manhood, while he had found it necessary to toil for pre-eminence and position, he had so vigorously applied his learning, as occasions of display offered, that the restamping of it on his memory had given a deep tinge of philosophy to his thoughts; and all his conclusions appeared as the bright results of intuitive sagacity. He was only not a pedant because he was a genius: for the apt quotation so harmonized in his sentences and illustrated his meaning, that his reflections seemed to be original, and his mosaic phrases deserved for their elegance to be considered his own. ${ }^{216}$

There is much more than one might extract from the addresses, such as the sources they use, how the orators draw on ideas of history, moral philosophy; how proslavery thought fit with American identity; did southerners believe in progress through slavery?

The orations illustrate the values of the era. They may serve as a way of expanding the map of the mental universe that antebellum Alabamians inhabited. The orations explain the role of the University in Alabama society and some of the ideas of antebellum intellectuals. Given the relatively small number of orations that have survived-less than twenty between 1840 and the beginning of the Civil War-it is not possible to construct from them a complete catalog of the ideas in circulation. There is a striking difference between the University of Alabama addresses and many addresses to northern literary societies. The differences between Northern and Southern addresses correlates with differences between northern and southern thought, although a complete study awaits fuller reading in lectures at other southern schools. Some of those differences relate to the amount of proslavery thought and attacks on reform. That study of the differences must include important lectures from other Alabama institutions. ${ }^{217}$ It must also involve lectures from the Universities of South Carolina, Georgia, North Carolina, and

\footnotetext{
216 William Russell Smith, As It Is 37 (Albany, Munsell \& Rowland, 1860). Later in the novel, Smith provides a poem about the devil and the crisis over abolition, told through the allegory of a train wreck. See Ignipotence Abroad, in id. at 214-30.

217 See Edward Baptist, Address delivered before the trustees, FACUlty, And Student S of Howard College, Marion Perry County, November 16, 1846 (Tuskaloosa, AL : Printed by M.D.J. Slade, 1846); S. S.

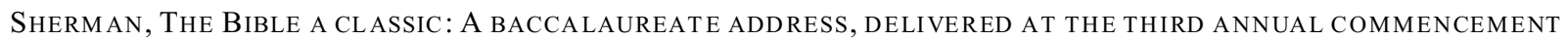
of Howard College, Marion, Ala., July 25Th, 1850 (Tuskaloosa M.D.J. Slade, 1850); Augustus Julian Requier, Address delivered by A.J. Requier, Before the Adelphi and Franklin Societies of How ard College, at the town of Marion, Alabama, on the 27th June, 1859; Noah K. Davis, The Progress and prospect of Alabama: AN Address delivered at the Co mmencement of How ARd College, June 29 Th, 1854. Literary addresses at La Grange College were MEEK, supra note 69; Hentz, supra note 21; E R WALLACE, AdDRESS Before the liter ary societies of La-Grange College. (1842); Robert Paine, Baccalaureate ad dress, delivered at the annual commencement of LaGrange College, June 8th, 1837 (1837); Joseph Cross, Preparatives of eloquence: An oration, delivered before the literary societies of La Grange College,

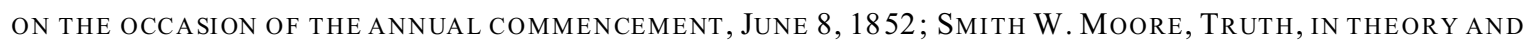
PRACTICE: AN ADDRESS DELIVERED BEFORE THE LITERARy SOCIETIES OF LA GRANGE COLLEGE, June 7, 1853.
} 
Mississippi. ${ }^{218}$ Of course even within the north, there are significant differences between the addresses; portions of some of the Northern lectures could have been delivered at Alabama. There is convergence in particular in the lectures given at northern schools by southerners, such as those by North Carolina Justice William Gaston at Princeton in 1835 and Virginia lawyer William Wirt at Rutgers in $1830 .^{219}$

We can use the Alabama orations to fill out a picture of the mind of antebellum Alabamians, which is a project that has made great headway and still promises to yield much more insight. ${ }^{220}$ The mind of the Old South, or maybe we should speak of the minds of the Old South, ${ }^{221}$ was developed at the antebellum University of Alabama. The orations are also important (and until now almost completely ignored) evidence of the rich intellectual life circulating in antebellum Tuscaloosa. Perhaps soon we will have a greater appreciation of the interplay of ideas in circulation at Universities and legal and political ideology and action.

\section{B. Ideas Into Action}

One always likes to be able to generalize from a limited set of data and, because the addresses are so rich in ideas, it would be particularly tempting to draw inferences about intellectual life in antebellum Alabama from these addresses. Yet, one may legitimately ask, what is the relationship between the literary addresses and larger thought? There are a series of increasingly difficult questions that one ought to pose about these addresses. Are they representative of the thoughts of Alabama faculty or students? Are they representative of elite Alambamians, such as judges, lawyers, legislators, or slaveowners? Do the addresses hold keys to the connections between Alabamaians' views on history and moral philosophy and legislative or judicial action?

Sometimes orators tell us about how they view the significance of the tradition of orations. Francis Gray told the Brown University Phi Beta Kappa Society in 1842 that the addresses impart enthusiasm for knowledge in their listeners and lead to discussion of the common interests:

\footnotetext{
218 See, e.g., Robert Livingston Stanton, Southern education: Addresses delivered in the Chapel at Oakland College, on the day of the annual commencement, June 29th, 1854 (New Orleans, The Picayune, 1854); Albert Gallatin Brown, An address on southern education: Delivered July 18, 1859, Before the faculty, trustees, students, and patrons of "Madison College," Sharon, Mississippi; Duncan Kirkland McRae, Love of Country: An address, delivered before the young ladies of the Clio Society of Oxford Female College, June 2D, 1864.

219 See GASton, supra note 62; William Wirt, AN ADDress DElivered Before the PEITHESSOPHIAN AND Philoclean societies of Rutgers College (New-Brunswick, N.J., Terhune \& Letson, 1830).

220 See, e.g., Guy Ward Hubbs, Guarding Greensboro (2002); J. Mills Thornton III, Politics and Pow er in a Slave Society (1979); William L. Barney, The Seces sionist Impulse: Alabama and Missis sippi in 1860 (revised ed. 2005); Charles B. Dew, Apostles of Disunion: Southern Secession Commissioners and the Causes of the Civil War (2002).

221 One must begin that analysis with Timothy Huebner, The Southern Judicial Tradition: State Judges and Sectional Distincitiveness, 1790-1890 (1999) and, for an earlier period, G. Edward White, The Marshall Court and Cultural Change, 1815-1835 (1988). See also EAton, supra note 61; E. Merton Coulter, College Life in the Old South (1928); Robert F. Price, Halls of Honor: College Men of the Old South (2004).
} 
Public lectures, and all other assemblages of men for literary of scientific purposes, are also worthy of encouragement, though the knowledge obtained in them is, for the most part, superficial and incomplete. They can deter no reasonable being, otherwise disposed to it, from the thorough investigation of any subject; but on the contrary, by exciting curiosity, may induce many to enter on studies, which they would not else have thought of pursuing. Such meetings, too, of persons of different occupations and positions in society, to engage in the same pursuit, and share the same pleasure, tend greatly to remove mutual prejudices, and to facilitate intercourse among them by affording them topics of common interest. ${ }^{222}$

Historians have mined literary addresses for a variety of purposes. Most profitably, they allow us to peer inside the minds of the orators. ${ }^{223}$ Even in those cases, we must be cautious about drawing inferences, for the ideas may represent only what the orator believes he ought to project to the audience. Yet, they at least allow us to form some judgments about the orators' intellect, interests, and knowledge, as well as the belief systems they associate with in public.

In the case of the antebellum University of Alabama, we can see a general trend moving toward support of a distinct world of hierarchy. That world needed a justification and received it. There are certainly lectures that break free of that model, such as Burwell Boykin's which addressed the importance of scientific advances. ${ }^{224}$ But by comparison with literary addresses at New England colleges, there are some distinct differences. There is little in the way of celebration of general human progress, ${ }^{.25}$ there is instead an emphasis on progress of limited groups and the celebration of differences between those groups. During Tutwiler's time the role of scholars is celebrated; after his departure, the University is praised for the defense its students offer to Southern institutions-to the wealthy and the established. ${ }^{226}$ The issue for the University,

\footnotetext{
222 Francis C. Gray, An Oration Before the Phi Beta Kappa Society of Brown Univer sity, Providence, R.I. on Commencement Day, September 7, 1835, 35 (Providence: B. Cranston \& Co., 1842).

223 See, e.g., Welter, The Mind of AmericA, supra note 24.

224 BURR, supra note 3.

225 A sampling of the Phi Beta Kappa orations that celebrated progress in the antebellum era includes: LEVI Woodbury, An Oration before the Phi Beta Kappa Society of Dartmouth College 4 (Darmouth Press, Hanover 1844) ("The, loom is still in some, countries mere sticks, driven into the ground, instead of the intricate machinery, suited, as with us, to weave the most beautiful fabrics, in every color of the rainbow, and in almost every figure of nature or the kaleidescope, or the richest fancy."); Joseph Ingersoll, An AdDress DeliVERED Before the Phi Beta Kappa Society, Alpha of Maine in Bowden College 13 (Brunswick, 1837); Dennison Olmstead, An Oration on the Progressive State of the Present Age. Delivered at New Haven Before the Connecticut Alpha of the Phi Beta Kappa, September 11, 1827 (Hezekiel Howe, New Haven 1827).

At the times when the Alabama lectures talk about progress, it is a celebration of the liberty that has been attained for a limited group and what must happen to sustain that liberty, rather than the promise that United States liberty holds out for others. Francis C. Gray, An Oration before the Phi Beta Kappa Society of Brown University... September 7, 184220 (B. Cranston and Co., Providence 1842) ("other nations, influenced by our example, will catch and foster the sacred spark of liberty, so that, if our light should subsequently be quenched, new beacons will then be already kindled for the guidance of those who shall still remain in darkness.").

226

See, e.g., TAYLOR, supra note 144, at 24.
} 
as for other throughout the South, was conservativism or reform.

The comparison between Tutwiler and Joseph Taylor's 1847 address is particularly stark, because Taylor focuses particular attention on the utility of the University to Alabama. His address emphasized the utility of education to the state in supporting Southern institutions, rather than its oppositional role. Precisely in his selection of topic, Taylor links the University to the powerful. Taylor saw southern colleges, the southern pulpit, and the southern press, as the defenders of slavery:

The sons of the South are its legitimate, its reliable, and its appointed defenders; and, in the Universities of the South, must they be imbued with the skill and force in the use of the weapons of reason necessary to the high encounter to which they are called. If they be educated elsewhere, may they not imbibe the doctrines of our assailants, and thus, returning to us in the guise of friends, help to drag over the walls and into the very citadel of our domestic Troy, some fatal horse pregnant with the impediments of fanatic propagandists and unreformed reformers? $?^{227}$

There was much to that celebration of the role of Alabama's students, for they were drawn from the ranks of the wealthy and they were destined in many cases for important roles in antebellum history. The University was an important training ground for those who would hold power and an important proving ground for their ideas. ${ }^{228}$ Taylor's other work suggests that he was a conservative Whig. For instance, he delivered an obituary on Henry Clay in 1852 and he delivered several addresses to other literary societies. ${ }^{29}$ He also served as president of the board of trustees of Southern University in Greensboro. So Taylor was well-familiar with the justifications for University education and his views are worth particular attention. The justification is set on utilitarian principles.

With some, the connections between ideas expressed at the University and in the

\footnotetext{
227 Id. at 25. Orators at other schools made similar points to Taylor. In the immediate wake of the Compromise of 1850 , for instance, an orator at nearby How ard College in Marion, Alabama emphasized the utility of education in southern values. See T. G. KeEn, Characteristics of THE TIMES, STRONG INCENT IVES to INTELLECT UAL EFFORT AN ADDRESS DELIVERED Before the Franklin \& Adelphi Societies of How ARd College at their ANNiVersary, held at Marion, Alabama, July 24, 1850 (Franklin \& Adelphi Societies, M.D.J. Slade, Tuskaloosa, Ala.1850).

228 One way of gauging this is consultation of the list of students in 1854 with their families' wealth in the 1850 census. See Catalogue of the Officers, Alumni, and Students of the University of Alabama, 1821-54 2932 (Tuskaloosa, M.D.J. Slade, 1854) (listing students and their home counties).

229 Joseph Wright Taylor, Henry Clay, his life, Character and SERVices: An Oration Delivered Before a Meeting of the citizens of Greene County, Alabama, at Eutaw, July 31 st, 1852 (Eutaw, William H. Fowler, 1852); Joseph Wright Taylor, The young American: His EduCAtion, duties, AND REWARDs; AN AdDress delivered before th Adelphi and Franklin Societies of How ard College, on their Anniversary occasion, July 26, 1849 (New York: Lewis Colby, 1849); Joseph Wright Taylor, The Southern University: ITS ORIGIN, PRESENT CONDITION, WANTS, AND CLAIMS : AN ADDRESS DELIVERED BEFORE THE BELLES LETTRES AND Clariosophic Societies of the Southern University, on their anniversary occasion, July 2, 1861 (Nashville, Tenn.: Southern Methodist Pub. House, 1861). See also William May Wightman, Inaugural AdDress delivered at the o pening of the Southern University, Greensboro, Ala. 9 (1859) (through liberal education the mind "is thus less in danger of becoming a mere cog or band in the vast machine to which our modern utilitarianism would fain reduce society.”)
} 
legislatures or courts was direct, as illustrated by Supreme Court Justice John A. Campbell's 1859 address. Likewise, Benjamin Porter, who addressed the University literary societies twice, provided very direct connections to the outside world. He represented Tuscaloosa in the Alabama legislature. ${ }^{230}$ He was also author of several important legal volumes. ${ }^{231}$ United States Senator from Alabama, C.C. Clay, delivered an address in 1855. We can link his thought together with several speeches given in the Senate. On April 21, 1856, he opposed the admission of Kansas as a free state. ${ }^{232}$

We can see the connections between legal thought and literary addresses by looking at the moral philosophy of Alabama jurists. Often as they justify their opinions they illustrate the complex world of hierarchy that motivated both jurists and professors. As William Smith's study Professors and Public Ethics found, the world of the antebellum college provided a language for categorizing and thinking about the world. A multiple regression equation that contains reverence for precedent, moral philosophy and understanding of history and society explains much of the behavior of antebellum Alabama jurists.

Where other historians have emphasized the division between the intellectual and society in the antebellum south, looking to judges reminds us that there was a vibrant social mind in the antebellum South-and that frequently the defense of slavery received some of its strongest

\footnotetext{
230 Benjamin F. Porter, Argument of Benjamin F. Porter in support of a bill, int roduced by him, in the House of Representatives of Alabama, to abrogate the punishment of Death (Tuscaloosa: J. M'Cormick, 1846); Benjamin F. Porter, The Value of ourselves and the times in Which we live. The Substance of an EXtem Porary address, SPOKEn before the Ciceronian and Phi Delta Societies of Mercer University, Ga., ON COMmen CEMEn t DAY, July 25, 1849 (Penfield, Ga., Temperance Banner Office, 1849); BenJAMIN F Porter, A Vindication of the Profession of lawy ers (Athens, Ga., Gazette Job Establishment, 1849); Benjamin F. Porter, Outlines of the oration of Judge Porter: Before the Republican Society, ANd other Citizens of Tuskaloos a County, at Hopewell, July 4, 1845 (Tuskaloosa, M.D.J. Slade, 1845).

231 Benjamin F Porter, The office And duties of EXECUtors AND ADMINISTRAtors, Being A PLAIN AND SIMPLE TREATISE ON THE RIGHTS, RESPONSIBILITIES AND DUTIES OF THESE OFFICERS; CONTAINING DIRECTIONS WITH REGARDS TO THE MAKING OF WILLS, DISTRIBUTION OF ESTATES, AND OTHER NECESSARY ACTIONS TO WHICH IS ADDED, FORMS AND ENTRIES FOR JUdGES AND CLERKS OF THE ORPhANS' COURT (Tuskaloosa [Ala.], M.D.J. Slade, 1842); BENJAMIN F Porter, a Collection of the Principles of the Common and Statute Law Relating to the Office of

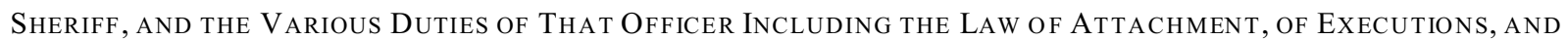
Forms of Proceedings, Particularly Adapted to the States of Alabama and Mississippi, with a Copious InDEX (Tuskaloosa, M.D.J. Slade, 1846).
}

232 Cong. Globe, $34^{\text {th }}$ Cong., $1^{\text {st }}$ Sess., app. 481 (April 21, 1856); Congressional Globe, $34^{\text {th }}$ Cong., $1^{\text {st }}$ Sess., 1405 (June 12, 1856) (remarking on New England senators' treatment of southern senators, as slaveowners); Southern Rights, How Menaced by Northern Republicanism, Cong. Globe, $35^{\text {th }}$ Cong., ${ }^{\text {st }}$ Sess., App. 144-49 (March 19, 1858 ) (discussing admission of Kansas, especially Constitution's limitation on federal government to limit property rights in humans). Clay was a prominent supporter of a bill to compensate Alabama and Georgia citizens whose property was destoryed and whose lives were lost during the Creek uprising in 1836. Clay remarked that "if the Government fails to preserve the property of its citizens or prevent the loss of its property, when it is entirely practicable, and when urged and entreated to do so, it should afford indemnity." Clement C. Clay, Creek Spoilation, Cong. Globe, $35^{\text {th }}$ Cong., $1^{\text {st }}$ Sess. 2052 (Aug. 12, 1858). See also Speech of Hon. C.C. Clay, Jr., of Alabama, in the Senate of the United States Opposing Land Grants for Colleges, Cong. Globe, $35^{\text {th }}$ Cong., $2^{\text {nd }}$ Sess. $851-54$ (February 7, 1859); Delivered in the Senate of the United States, June 28, 1854; Remarks of Senators Clay of Alabama, Cong. Globe, $36^{\text {th }}$ Cong., $1^{\text {st }}$. Sess. 121-24 (December 13, 1859) (on resolution regarding “Invasion of Harper's Ferry"). 
support from the judiciary. Where Drew Faust wrote of a Sacred Circle of intellectuals who were isolated, in antebellum Tuscaloosa, there were close connections between the politically powerful and the intellectuals. Those close connections (and fairly wide interest in the literary addresses) suggest that intellectuals occupied a more important place in antebellum Tuscaloosa than Faust suggests for her sacred circle. The life of the mind, concerned though it was for the hierarchy and preservation of the system as it was, was popular. The literary addresses were, as David Moltke-Hansen tells for Charleston, a social event. ${ }^{233}$

Close reading of cases is extremely helpful in figuring out what judges are doing. Are they concerned with efficiency or redistribution of property. ${ }^{234}$ What motivates judges? We should look to what they say, to see how they believe their decisional process works and what factors are important to them in making decisions? Judges will not necessarily say something inculpatory and there is often public dissembling about motives. We have seen that often in public discussions of slavery. Nevertheless, we should at least ask the participants what they thought was happening. Often when we ask those kinds of questions, we receive important insight. Rush Welter, Perry Miller, Daniel Walker Howe all harnessed the techniques of intellectual historians-a close read of public addresses, as a way of diving the complex grid of ideas of antebellum Americans. For public statements tell us how orators want us to believe they think.

The University of Alabama talks were delivered by a United States Senator, a United States Supreme Court Justice, and numerous local legislators and lawyers, as well as those who would serve as legislators. They illustrate the belief of those politicians and intellectuals in the importance of education and the role of the educated in governing society. The sophisticated addresses spoke of the connections between a people's history and its morality, its history and culture and its legislation. They spoke of the utilitarian spirit of the age and the need to discipline that spirit with morality. Similar ideas motivated the judges. Thus, they remade the law, as a generation of legal historians have said, to bring it into line with ideas about expediency and progress, even as they sought to leaven those changes with attention to precedent and to humanity and considerations of morality. The addresses help construct a picture of the matrix that judges and legislators employed to reach decisions in concrete cases and on specific legislation.

Judges in Alabama sometimes spoke of those considerations of history and of morality in their opinions. In Caldwell v. State all three members of the Alabama Supreme Court issued seriatim opinions on the question of the state's jurisdiction to punish a white man for the murder

\footnotetext{
233 David Moltke-Hansen, The Expansion of Intellectual Life: A Prospectus, in InTELLECTUAL LIFE IN Antebellum Charleston (Michael O’Brien \& David Moltke-Hansen eds. 1986). See also David Moltke-Hansen, Ordered Progress: The Historical Philosophy of William Gilmore Simms, in Long YeARs of NegLeCt: The Work and Reputation of William Gilmore Simms 126 (John C. Guilds ed. 1988) (emphasizing connections between order and progress).

234 See, e.g., Jenny Wahl, The Bondsman's Burden: An Economic Analysis of the Common Law of Southern Slavery (1998); MCCurdy, supra note 13 (placing judicial opinions in the context of Democratic and Whig politics in antebellum period).
} 
of a Creek Indian for homicide. ${ }^{235}$ Caldwell turned on whether the state had jurisdiction to punish crimes occurring on tribal land located within the state of Alabama? ${ }^{236}$ Chief Justice Abner S. Justice Lipscomb upheld Alabama's power (derived in turn from Congress' power) to pass legislation punishing murder and thus upheld the death sentence against the white man. Thus, Lipscomb was able to use the need to punish the murder to secure the state's jurisdiction over land inhabited by natives. He thus limited native rights of sovereignty. Lipscomb reasoned, as had Chief Justice John Marshall nearly a decade earlier in Johnson v. McIntosh, to the natives' limited rights to the land they inhabited, from the fact they were savages, who did not possess the attributes of sovereignty. ${ }^{237}$ Lipscomb employed his understanding of native society to deprive them of the rights of sovereignty, for he found the native societies to be nomadic and without an "established system of government." 238 Or, "the pretension of those who live by the chase, must yield to the cultivator of the soil." 239

Justice Taylor's opinion surveyed much colonial and national history to assess the rights of the natives to the land. He recalled that until recent years, the natives had been the "undisputed lords of this immense continent." Some might conclude from that history that the natives should maintain sovereignty over the lands they occupy. "Such reflections excite a warm interest in behalf of the Indian, and we listen to his complaints fully prepared to believe that he has been injured. Similar feelings have been general throughout the union, and, doubtless, they have often controlled the intellect, and commanded the judgment, when forming an opinion upon the rights of the states over these rude nations." ${ }^{40}$ But those feelings of the heart did not hold sway in the Alabama courts-nor in any others, it seems. ${ }^{241}$ For the court justified the continued occupancy of the land. Against the suggestion that "unholy acquisitions be immediately surrendered" and that the current inhabitants "make restitution," the court had a justification. When they found the land "in a state of nature, our forefathers were justifiable in clearing away the forest and cultivating the fields formed by their industry, and in bringing the Indians into

\footnotetext{
235 See also Tim Alan Garrison, Beyond Worcester: The Alabama Supreme Court and the Sovereignty of the Creek Nation, 19 Journal of the Early Republic 423-450 (1999).

2361 Stew. \& P. 327, (Ala. 1832) (construing jurisdiction to try white man for murder of Creek Indian).

237 Id. at 332-33 (citing Johnson v. McIntosh, 23 U.S. 543 (1823); Goodall v. Jackson, 29 Johns. R. 693 (1823)).

$238 \quad$ Id. at 333.

239 Id. at 339

$240 \quad I d$. at 444.

241 On the place of sentiments of humanity and cold legal logic in antebellum legal thought, one might begin with Lawrence Friedman, Heart Against Head: Perry Miller and the Legal Mind, 77 Yale L.J. 1244 (1968) and Losing One's Head: Judges and the Law in Nineteenth-Century American Legal History, 24 L. \& Soc. INQUIRY 253 (1999). One profitable, but as yet underused method, is looking at what jurists said about their methods. See, e.g., Legal Education, 14 S. Q. REV. 432 (1848); addresses to law students at Transylvania....
} 
subordination to them by the best means which policy and humanity dictated." 242

Justice Taylor wrote, much as later college orators did, of the progress in society. He found progress in the growth of cities, the commerce, the development of agriculture, and the growth of political institutions. That progress led the Justice to believe that the natives had no claim to sovereignty or land in Alabama.

But when we contemplate the change which has been wrought in this once savage wilderness, by the arts, the industry, and the superior knowledge of the new population; when we visit our thronged cities, smiling fields, and happy habitations; when we contemplate our numerous bays and harbors, once the resort only of the wild fowl and the inhabitants of the deep; now studded with ships and vessels of all sizes and nations, pouring upon these lands the rich and extensive commerce of a whole world; when, instead of a roving tribe of hunters, we behold a powerful nation of agriculturists, as free in every desirable liberty, as their savage predecessors; when our happy political institutions and the religion of the Bible, have displaced their barbarous laws, and wretched superstitions; can we wish these effects of civilization, religion, and the arts, to disappear, and the dark forests and roaming Indian again to possess the land?

The court found, as did later orators, the hand of providence in the changes: "Are we not compelled to admit that the superintending providence of that Being who first formed the earth, is to be seen in this mighty change?"243 The language by which Alabamians spoke of their progress appeared in judicial opinions, as well as in college addresses. That is as one would expect. For as Justice John Campbell said, law and community sentiment work together.

Caldwell provides an important connection between the reasoning styles of judges and the college orators. Across 120 pages of legal reasoning, there was much discussion of history and expediency, of reasoning based on understandings of human nature, and of a justification of the system as it existed. The extensive reasoning and discussion of precedent reminds us of the importance of ideas-and particularly of ideas in books-to lawyers. The jurist was expected to be a master of precedent and often displayed that learning. Those who lacked books were considered to be inadequate lawyers, as a short story printed in Mobile in 1837 about a lawyer who was lazy suggested. The author lamented that the once-hard working lawyer's office had declined from one with many books, to a few books and an old map of the United States. "A dirty and ragged set of Blackstone, a coverless Digest, and an odd copy of a Law Dictionary, compose the ready part of his office." 244

Caldwell was a critically important case, as the space that the judges devoted to it suggests. The language of civilization appeared again, several decades later. The Alabama Supreme Court looked back in 1857 to the Creek Treaty of 1832 with approval, for that domesticated some natives and brought them into the support of the idea of private property:

The treaty of 1832 made the first clear and distinct advance towards localizing and individualizing the tract of the individual Indian, as distinguished from the nation in its

\footnotetext{
$242 I d$. at 425 .

$243 \quad I d$. at 445.

244 H.. Thompson, The Confessions of a Ci-Devant Politician, BaChelor's Button 207, 209-10 (1837).
} 
aggregate capacity. It inaugurated the great feature of civilization and christianity, of giving to individual rights the strong arm of government as a shield against lawless aggression; of identifying the locality of the individual, and associating his name with his place; thus clustering his affections about his corn-patch and hearth-stone, and making his house a castle of defense. ${ }^{245}$

In other significant cases, judges employ a similar range of sources for law, such as understanding of history, their interpretation of Alabama culture. They also, of course, employed a close reading of statutes and of legal precedent. They took general principles of moral philosophy and legal reasoning and put specific cases into that framework. Throughout the antebellum period, for example, the Alabama Supreme Court struggled with interpreting wills that freed slaves. Trotter $v$. Blocker, for example, prohibited emancipation by will. Justice Collier concluded that restraints on disposition of property by will (at least in the form of emancipation) was "the dictate of a wise policy." He thought the policy wise because:

As a measure of expediency, the State owes it to its citizens at large, to protect their interest, by throwing suitable guards around the institution of slavery. If emancipation were allowed, at the mere volition of the master, consequences, disastrous to the quiet of the country would likely result,-the public would be burthened with the charge of more paupers than it would be convenient to support, and slaves, themselves, would be turned loose upon society, who either from age, or the want of it, could not provide the comforts, or even the necessaries of life. And last, though not least, the demoralizing tendency of such a policy would be such as should induce every christian and philanthropist to deprecate its toleration. ${ }^{246}$

Later, in 1852 in Atwood's Heirs v. Beck, the Alabama Supreme Court faced a more difficult question: whether a will requiring the executor to take slaves out of the state and free them was valid. Frederick Beck, who had addressed the Erosophic Society as a student in 1835, was the executor of the estate and he wanted to send the slaves to Ohio and emancipate them. Here the court faced the seemingly contrary precedent of Trotter, but it parsed the facts differently. Chief Justice Chilton surveyed much precedent. He noted the special attention the legislature had given slaves. "This general power which the master has over the slave, both in respect to his treatment and manumission, has been controlled and guarded by legislative, checks, prompted alike by humanity for the slave and security for the State." ${ }^{247}$ After commenting on the right of lords to emancipate their villeins in medieval England and parsing a series of conflicting precedents in other southern states, ${ }^{248}$ the court upheld the will. For an owner might take the

Rose v. Griffin, 33 Ala. 717, (Ala. 1859).

246 Ala. (6 Porter) 269, 293 (1838).

24721 Ala. 590, $608(1852)$.

248 Chilton cites, among other sources, George Crabb's History of English Law (1829), C.C. Clay's Digest of Alabama Law, multiple seventeenth and eighteenth century English cases, Justinian's Institutes, Wheeler's Law of Slavery, and Pleasants v. Pleasants, __ Va. (2 Call) 270 (1799); Fisher's Negroes v. Dabbs, _- Tenn. (6 Yerg.) 119 (decided by future Supreme Court Justice Joseph Catron); Frazier v. Frazier's Executors, _-_ S.C. (2 Hill's Ch.) 304; and Leech v. Cooley, __ Miss. (6 Sm. \& Mar.) 93; Vance v. Crawford, 4 Ga. 445, among many others. 
slaves out of the state himself, so that an order in a will to an executor to take the slaves from the state and then free them was merely an exercise of the owner's pre-existing right.

There are other places in the Alabama reports that one can view more fleeting glimpses of the reasoning styles of judges and their connections to college moral philosophy or to the wonderment at technological and economic progress. When the Alabama Supreme Court faced the perplexing question whether aliens should be allowed to purchase land, it returned to speculation on the nature of political thought. In 1830 in Jinkins v. Noel, the court concluded that both precedent and political theory ("the spirit of our institutions"), supported alien land ownership. ${ }^{249}$ In deciding whether a book might be entered as evidence in 1857, the Alabama Supreme Court recalled how important printing had become in transmitting knowledge:

It is the boast of this age of advancing civilization, that, aided and facilitated by the printer's art, the collected learning of past ages has been transmitted to us. Shall we withhold the benefits of this heritage from the contests of the court-room? We think not. Evidence drawn from this source being admissible, the question arises, in what form is it to be laid before the jury? Are opinions, derived from the perusal of books, and deposed to by witnesses, safer guides for that body than the books themselves are? ${ }^{250}$

At other times, judges spoke of the genius of political institutions and of the equality of people across wealth. Thus, in 1860 the Alabama Supreme Court refused to allow damages in defamation actions to turn upon considerations of a person's status (or not) in a profession:

We are not able to discover any sound principle, on which the plaintiff's high or humble rank in society, dissociated from his character, can be held a proper matter for consideration in determining the amount of damages he should recover. It is often the case that the greatest worth of character is found in the humblest ranks of life, and that to persons in those ranks a good character is more valuable, and slander more injurious, than to those who are above them in social position. It is equally true, that persons destitute of

2493 Stew. 60, (Ala. 1830).

250 Stoudenmeier v. Williamson, 29 Ala. 558, (Ala. 1857). The court went on to employ an analogy to the common law. Judges learn what the law is by reading books; hence, evidence about medicine found in books ought likewise to be admissible:

A principle, familiar to every member of the legal profession, is strongly illustrative of the propriety of admitting the evidence we are considering. The body of our laws, known as the common law, is generally understood to be unwritten. We prove its existence and its principles by reported cases, and standard elementary writers. With what consideration would an objection be entertained, which on this subject denied the right to consult Coke, Bacon, or Blackstone? All these were elementary writers, and yet they are conceded to be of the highest authority. If it be objected that the books above named are not laid before the jury for their consideration, but are weighed and expounded by the court, the answer is, that that grows out of the nature of the subject of which they treat. Under our system, questions of law are exclusively for the court, and with them the jury have nothing to do. All inquiries respecting any other science are questions of fact, for decision by the jury. Can that be a sound rule, which, in the determination of a question involved in one science, allows to the trying body the light shed upon it by the writings of its standard authors, and withholds such lights from controversies respecting all other sciences? We think not.

Of course, when figuring out what the Alabama common law is, Alabama judges preferred to look to other southern states. See, e.g., Metcalf v. Watkins, 1 Port. 57, Ala. 1834 ("In view of the honor due to the genius, learning and literature of my native state, I prefer instruction in jurisprudence from Roane, Carr and Greene."). 
the qualities which make character valuable are found in what is denominated the highest rank in life, and in all the professions, the sacred ministry not excepted. ${ }^{251}$

A systematic study of places where moral philosophy influenced the evolution of the common law is necessary. We are still far from a comprehensive picture of antebellum legal thought, particularly in the south. Yet, perhaps those few examples will suggest some of the connections between literary and legal culture, as well as the promise of reconstructing the matrix of ideas that informed judges from such sources as literary addresses.

As judges struggled with mixing considerations of utility and morality, progress, Christianity, and the community they often arrived at differing results. But those are key factors they brought to bear in their reasoning. As they groped toward results, they employed a host of considerations in deciding cases.

Often, though, judges felt constrained by legislation and precedent. If one wants to see the connections between the moral philosophy of the orators and public action, it might be most easily seen in legislative debates. For there, and particularly in debate over secession, Alabama legislators employed that same reasoning from history, utility, and a consideration of the world as it is appeared and as they understood it to be. For example, William Russell Smith, who delivered the last published literary address before the Civil War, was one of Tuscaloosa's delegates to the secession convention in Montgomery. He spoke about the morality of the slave trade and slavery itself:

I hold, that the African, taken from his native wilds and placed in the ranks that march onward from savage to civilized life, is greatly benefitted. He is humanised and christianised. He rises from the condition of a brute into the position of a christian man. The present condition of the Alabama negro, illustrates this. Place a native African side by side with an Alabama negro--how vast is the difference in stature as well as in intellect. The one has the graceful and sinewy limbs of a Hercules--the other is a mere mongrel. In nine cases out of ten, in positive contentment, the Alabama slave is happier than his master. His cottage is built for him, his food provided, his meals prepared; his hearth to spread with substantial comforts, and his long nights are for those blissful dreams that are undisturbed by the knowledge of coming necessities. He has no cankering cares, no buffetting with fortune, no aspiration for expanding acres, no cares for rain or sunshine. He has neither cloth nor meat to buy; he is free from debt, he is above all civil law--and he looks forward to Christmas, not as the maturity time for his bills, but for his holidays. Sir, there can be nothing immoral in placing a savage in such a condition as this. ${ }^{252}$

Representative Smith illustrates the connections between the intellectual and the men of action, who employed the same reasoning styles and modes of argument. Such are some of the longhidden connections between the worlds of the mind and of action in the old South.

\footnotetext{
251 Gandy v. Humphries, 35 Ala. 617, (Ala. 1860).

252 William R. Smith, The History and the Debates of the Convention of the People of Alabama, Begun and Held in the City of Montgomery, on the Seventh Day of January, 1861201 (Montgomery, White Pfister \& Co. 1861).
} 
TABLE 1

Orators, Society Sponsoring, and Age at Time of Oration

\begin{tabular}{|c|c|c|c|c|c|}
\hline Date & Erosophic & Philomathic & Joint & Alumni & PBK \\
\hline 1832 & Hilliard & & & & \\
\hline 1833 & Brumby & Jones & & & \\
\hline 1834 & Tutwiler & & & & \\
\hline 1835 & Beck & & & & \\
\hline 1836 & & Porter & & Meek & \\
\hline 1838 & & Brumby & & & \\
\hline 1839 & & & & Crenshaw & \\
\hline 1840 & Hayne & & & Teague & \\
\hline & & & Wood & & \\
\hline \multirow{2}{*}{\multicolumn{2}{|c|}{1841 Hamilton }} & Cochran & & Pickens & \\
\hline & & & Gates $4^{\text {th }}$ of $\mathrm{Ju}$ & & \\
\hline 1842 & Simms & & & & \\
\hline 1843 & Hentz & Foster & & Forney & \\
\hline 1844 & & Huntington & & & \\
\hline \multirow[t]{2}{*}{1845} & Porter & & & & \\
\hline & & & Lipscomb & & \\
\hline \multicolumn{6}{|l|}{1846} \\
\hline 1847 & & & Taylor & & \\
\hline 1848 & & & & Smith & \\
\hline \multirow[t]{2}{*}{1850} & & & & Pratt July $8^{\text {th }}$ & \\
\hline & & & & Shortridge & \\
\hline 1854 & & & & & Barnard \\
\hline 1855 & & & Clay & & \\
\hline 1857 & & & Boykin July $4^{\text {th }}$ & & \\
\hline 1858 & & & Bullock & $\begin{array}{l}\text { McMullen July } 4^{\text {th }} \\
\text { Stausel }\end{array}$ & \\
\hline 1859 & & & Campbell & & Lord \\
\hline 1860 & & & & & Smith \\
\hline & $9 \mathrm{E} \quad 6 \mathrm{P}$ & & 8 & $10 \mathrm{~A}$ & $\begin{array}{l}3 \mathrm{PBK}: 36 \\
\text { total. }\end{array}$ \\
\hline
\end{tabular}

Pickens and Stausel remain unpublished. 
